\title{
COMMENT
}

\section{TROUBLES AT THE DOORSTEP: THE FAIR HOUSING AMENDMENTS ACT OF 1988 AND GROUP HOMES FOR RECOVERING SUBSTANCE ABUSERS}

\author{
LAURIE C. MALKIN†
}

\section{INTRODUCTION}

The streets are quiet and tree-lined. The homes, comfortable and well-maintained, are encircled by green lawns and separated either by picket fences or by driveways accommodating parked station wagons. Children play a game of tag at one end of the block, while mothers talk over their morning coffee at the other. The American Dream-to live in a single family-home in suburbiaappears to be alive and well. ${ }^{1}$ Is it?

Not everyone is welcome to reside in these cozy homes. Recovering alcoholics and former drug addicts are often excluded from this vision of the community ideal. Despite community opposition however, increasing numbers of recovering substance abusers are attempting to establish group homes ${ }^{2}$ in single-family residential neighborhoods. ${ }^{3}$ These democratically run houses, modeled upon self-help programs such as Alcoholics Anonymous, ${ }^{4}$

† B.A. 1990, Wesleyan University; J.D. Candidate 1996, University of Pennsylvania. I would like to thank Professor Michael Schill for sponsoring my independent study and for his guidance. Joel Millar, Pamela Reichlin, Andrew Schiesl, and the members of the Law Review also deserve many thanks for their valuable suggestions and careful editing. I am especially grateful to Karin Guiduli, Jeffrey Peters, Gregory Sirota, Jessica Weiner, and Lisa Winsheimer for their encouragement. This Comment is dedicated to my family, with love.

I For a similar depiction, see Steve Mitra, Home Stands Alone; House for Recovering Addicts Is Opposed By Neighbors, Officials, NEwSDAY (N.Y.), Oct. 6, 1991, at 1 (describing the perception of East Farmingdale, N.Y., residents who attempted to prevent the establishment of a group home for recovering substance abusers).

2 These living arrangements are described herein as either group homes or recovery houses.

${ }^{3}$ Oxford House, the nation's largest provider of group homes for recovering substance abusers, has grown from one home in 1975 to 534 homes in 36 states and the District of Columbia in 1994. See H. Jane Lehman, Supreme Court to Hear Case on Group Homes: Oxford House Challenges Limits on Residents As Discriminatory, WASH. POST, Dec. 17, 1994, at E1, E5.

+ See J. PAul Molloy, Self-Run, Self-Supported Houses for MORE EFfective 
have contributed to the effective rehabilitation of former drug and alcohol abusers. ${ }^{5}$ Recovery houses for former substance abusers are similar to group residences for the elderly, the mentally and physically disabled, AIDS patients, and troubled teenagers in that they serve individuals struggling to develop healthier, more stable, independent lifestyles. ${ }^{6}$ Shared living arrangements located in residential neighborhoods succeed because they provide the right environment. ${ }^{7}$ Furnishing former addicts, a population desperately in need of safe, affordable housing, ${ }^{8}$ with a structured and supportive milieu, however, evokes immense local opposition.

Resistance to group homes for recovering substance abusers takes many forms and varies in intensity. Local opposition to these and similar programs has ranged from signed petitions ${ }^{9}$ to acts of arson $^{10}$ but is most often manifested by the use of municipal zoning laws. By requiring special permits, ${ }^{11}$ invoking public notice

ReCOVERY FROM Alcohol AND DRUG AdDiction 7 (Alcohol, Drug Abuse \& Mental Health Admin. Technical Assistance Publication Servs. No. 5, 1992).

${ }^{5}$ See infra note 34 and accompanying text (discussing the success rates of grouphome programs).

${ }^{6}$ See Cindy L. Soper, Note, The Fair Housing Act Amendments of 1988: New Zoning Rules for Group Homes for the Handicapped, 37 ST. LouIS U. L.J. 1033, 1040-41 (1993) (stating that the general goal of group homes is to help residents "become contributing members of society"); see also Kay Kusumoto, Home Gives Helping Hand to Addicts, SEATTLE TIMES, Nov. 9, 1992, at B1 (explaining how the purpose of Oxford House is to provide former addicts with sufficient support to discourage relapse and to integrate them into the community).

${ }^{7}$ See David C. Bell et al., An Experimental Test of Retention in Residential and Outpatient Programs, 20 AM. J. DRUG \& AlcoHol ABuSE 331, 338-39 (1994) (suggesting that a correlation exists between the close social relationships afforded by residential programs and effective drug treatment); see also MOLLOY, supra note 4, at 16 (commenting that houses located in good neighborhoods provide additional incentives for recovering addicts to remain clean and sober).

${ }^{8}$ See infra notes $39-44$ and accompanying text (discussing the need for affordable, stable, appropriate housing for former substance abusers in light of the close relationship between addiction and homelessness).

${ }^{9}$ See, e.g., Chilling HUD Complaint: The Wrong Way to Battle Neighborhood Activists, SEATTLE TIMES, Feb. 17, 1992, at A6 (editorial) (noting that more than 75 people signed a petition opposing the establishment of a group home for poor women recovering from drug or alcohol problems).

${ }^{10}$ See Letta Tayler \& Estelle Lander, Arson Target: Planned Northport Home for Mentally Retarded Damaged, NEwSDAY (N.Y.), June 9, 1992, at 3, 109 (describing how a group home was damaged by apparent arson after nearly 40 residents voiced their opposition to the home at a village board meeting and noting that the fire was the fifth instance of arson in a group home on Long Island, N.Y.), available in LEXIS, News Library, Arcnws File.

${ }^{11}$ See, e.g., United States v. Village of Palatine, 37 F.3d 1230, 1234 (7th Cir. 1994) (compelling an Oxford House to participate in a special-use permitting process before the local zoning board as a prerequisite to suing the municipality under the Fair 
requirements, ${ }^{12}$ and employing restrictive definitions that limit access to single-family residential neighborhoods, ${ }^{13}$ communities are frequently able to block the development of such residences.

At first glance, some of this protest seems reasonable. Many people work and save for years so that they can move into their own home. Purchasing a house is often a family's single largest expenditure. ${ }^{14}$ Furthermore, a home in a single-family residential neighborhood means more than the almighty dollar. ${ }^{15}$ People move to these neighborhoods to escape crime, drugs, and similar social ills. They seek out communities that share their values and interests. To members of these neighborhoods, it seems inconsistent at best and dangerous at worst to welcome into their midst houses full of former drug addicts and alcoholics.

Many courts have shared, or at least accommodated, this exclusionary perspective. ${ }^{16}$ Even those courts that do find exclusionary practices to exist sometimes inadequately assess and redress

Housing Act).

${ }^{12}$ See, e.g., Oxford House, Inc. v. City of Va. Beach, 825 F. Supp. 1251, 1255 (E.D. Va. 1993) (describing a zoning ordinance that requires both public notice and hearings prior to group-home approval).

${ }^{13}$ See, e.g., Smith \& Lee Assocs. v. City of Taylor, 13 F.3d 920, 925 (6th Cir. 1993) (permitting a city to require a rezoning hearing for Alzheimer's patients who sought to enter a neighborhood zoned solely for single-family homes); Elliott v. City of Athens, 960 F.2d 975, 983-84 (11th Cir.) (denying the zoning request of an Oxford House because the home exceeded the permitted maximum-occupancy limit), cert. denied, 113 S. Ct. 376 (1992).

${ }^{14}$ See, e.g., Walker Builders, Inc. v. Lykens, 628 So. 2d 923, 924 (Ala. Civ. App. 1993) ("The purchase of a home is the largest single investment that the average American family will make."); Hoke v. Beck, 587 N.E.2d 4, 7 (Ill. App. Ct. 1992) ("In many cases, the purchase of a home is the most important investment of a lifetime .... .); Calvert v. K. Hovnanian at Galloway, VI, Inc., 607 A.2d 156, 162 (N.J. 1992) ("For many people the purchase of a home will be the most significant financial transaction they will ever undertake."); Garcia v. New Mexico Real Estate Comm'n, 775 P.2d 1308, 1314 (N.M. Ct. App.) ("For many people, the purchase of a home is the largest investment they will make."), cert. denied, 776 P.2d 846 (N.M. 1989); Maack v. Resource Design \& Constr., Inc., 875 P.2d 570, 582 (Utah Ct. App. 1994) (“TT]he purchase of a home is often the single largest investment an individual or family will make....").

${ }^{15}$ See, e.g., Salka v. Dean Homes, 22 Cal. Rptr. 2d 902, 910 (Ct. App.) ("[T]he purchase of a home is not only the largest investment most people make in their lifetime, it is also a highly personal choice concerning how and where one lives his or her life.").

${ }^{16}$ See generally United States v. Village of Palatine, 37 F.3d 1230, 1234 (7th Cir. 1994) (vacating a preliminary injunction against a zoning restriction that limited the number of residents in a group home); Smith $\mathcal{E}$ Lee Assocs., 13 F.3d at 933 (reversing a district court's finding of intentional discrimination in the denial of a zoning request that would have allowed a group home to increase its number of residents). 
community efforts to discriminate against group homes from singlefamily residential neighborhoods. ${ }^{17}$ By viewing neighborhood zoning issues as the distinct domain of the locality, by failing to recognize the need for proactive measures, and by refusing to look beyond narrow conceptions of the family, courts allow persistent discrimination. This inadequate judicial enforcement forces former substance abusers who lack local power to battle against firmly entrenched community structures and stereotypes. Too frequently, former substance abusers lose this struggle between community interests and individual rights.

Despite extensive community opposition and insufficient judicial enforcement, group homes for former alcohol abusers and drug addicts should be accepted in single-family residential areas and should be accommodated by local zoning laws. This issue is certainly one that, in the most literal sense, will hit some readers close to home. The claim that former drug addicts and alcoholics must be allowed to reside in group homes situated in communities that they choose is not only controversial, but is often met with a visceral response.

This Comment provides a reasoned alternative to such resistance. Part I explains precisely why it is essential that homes in single-family residential neighborhoods be available to groups of former substance abusers. It briefly describes the magnitude of the drug and alcohol problem and demonstrates how group homes provide a necessary and effective step toward addiction recovery. Indeed, it is not only appropriate to integrate group homes for recovering substance abusers into single-family residential communities-it is the law.

Part II examines the Fair Housing Amendments Act of 1988 (FHAA) $^{18}$ and includes explanations of its basic provisions, the legislative intent that motivated its passage, and the methods of stating a claim thereunder. The FHAA enunciates a solid congressional policy regarding the rights of recovering substance abusers: (1) housing discrimination against people with disabilities is unlawful; ${ }^{19}(2)$ recovering alcoholics and former drug addicts are

${ }^{17}$ See, e.g., City of Edmonds v. Oxford House, Inc., 115 S. Ct. 1776, 1783 (1995) (narrowly addressing the issue whether a zoning regulation limiting occupancy to five or fewer unrelated persons was a use limit or a total occupancy limit).

${ }^{18}$ Pub. L. No. 100-430, 102 Stat. 1619 (codified at 42 U.S.C. $\$ \S 3602,3604-3631$ (1988)).

${ }^{19}$ See 42 U.S.C. $\$ 3604$ (stating that "it shall be unlawful . . [ [t]o discriminate in the sale or rental, or to otherwise make unavailable or deny, a dwelling to any buyer 
to be considered people with disabilities; ${ }^{20}$ and (3) discrimination against recovering substance abusers may be manifested in many ways, including intentional acts, unintended effects, and a failure to reasonably accommodate rules and practices, even when they are necessary to afford equal housing opportunity. ${ }^{21}$ The scope of the statute is sweeping, not only in the broad protections it affords, but also in the limited exceptions it allows.

The problem of community opposition to group homes for former addicts and inadequate judicial enforcement of the FHAA is outlined in Part III. This section first considers the "why" and "how" of municipal efforts to exclude houses for recovering substance abusers from single-family residential neighborhoods. It then describes how the judicial system has failed to address this problem. Courts often ignore clear congressional intent when interpreting the FHAA. As a result, discrimination against former drug addicts and alcoholics persists. The judicial system's reluctance has been most pronounced in its interpretation of the FHAA's definition of "reasonable accommodations."22 Part IV concludes the analysis of fair housing rights of group homes for recovering substance abusers. It recommends an alternative application of the FHAA, one that embodies the true intent of Congress and sufficiently combats discrimination against group homes for former drug addicts and recovering alcoholics.

or renter because of a handicap").

${ }^{20}$ See 42 U.S.C. $\$ 3602(h)$ (providing a broad definition of "handicap"); see also infra part II.A.2. Although the distinction is significant and the nature of both terms problematic, this Comment will employ interchangeably the terms "disability" and "handicap." See Penn Lerblance, Legal Redress for Disability Discrimination: Bob, Carol, Ted and Alice Encounter AIDS, 24 GOLDEN GATE U. L. REV. 307, 328 n.66 (1994) (discussing statutory uses of the terms "disability" and "handicap"). Congress replaced the term "handicap" with the term "disability" in its definition of statutorily protected persons when it passed the Americans with Disabilities Act of 1990. This change resulted from complaints that use of the word "handicap" helped to perpetuate stereotypes and patronizing attitudes toward such persons. See Preamble to Regulation on Nondiscrimination on the Basis of Disability in State and Local Government Services, 28 C.F.R. pt. 35 app. A (1994) (analyzing definitions found in 28 C.F.R. § 35.104 (1995)).

${ }^{21}$ See 42 U.S.C. $\$ 3604(f)(3)$ (delineating the forms of discrimination covered by the FHAA); see also infra part II.B (describing the prima facie case for proving an FHAA violation).

${ }^{22}$ See infra part III.B (discussing judicial analysis of the "reasonable accommodations" clause). 


\section{GROUP HOMES AND ADDICTION RECOVERY}

Communities may not always welcome group homes for recovering substance abusers, but they cannot dispute the fact that these programs work. The record on recovery houses is clearexperts, participants, and legislators agree that this mode of rehabilitation markedly improves individuals' abilities to free themselves from addiction and to meaningfully contribute to society. ${ }^{23}$ Given the magnitude and staggering consequences of America's substance abuse problem, steadfast support of this highly effective recovery program is imperative.

\section{A. Why Group Homes for Recovering Substance Abusers Are Needed}

Group homes for recovering substance abusers are necessary to combat the detrimental effects of drug abuse and alcohol dependence. Despite the War on Drugs and a national movement to stem alcohol abuse, the incidence of addiction in America remains staggeringly high. ${ }^{24}$ Yet numbers tell only a fragment of the story.

${ }^{23}$ See Oxford House, Inc. v. Township of Cherry Hill, 799 F. Supp. 450, 456 n.11 (D.N.J. 1992) (describing the testimony of Oxford House residents who found that the program makes "the difference of night and day" and the opinion of substance abuse experts who believe this living arrangement fosters community reintegration); Lawmakers Concerned over Implementation of Recovery Home Program: Group Homes for Recovering Alcoholics and Drug Abusers, AlCOHOLISM \& DRUG ABUSE WK., Apr. 26, 1989, at 3, 3 [hereinafter Lawmakers] (referring to a joint letter written by four House members in support of the Oxford House model in which they explained that Congress "selected Oxford House as a model because of its considerable success in reducing the rates of recidivism and in promoting long-term recovery"), available in LEXIS, News Library, Arcnws File; see also Kusumoto, supra note 6, at B1 (recounting the experience of one Oxford House resident who was able to prevent a relapse into drug addiction by participating in the program).

${ }^{24}$ The 1994 National Household Survey on Drug Abuse recently estimated that 18 million drinkers and 5 million drug abusers need treatment. See Abigail Trafford, Winners and Losers: A Look at the Past Ten Years, WASH. POST, Jan. 3, 1995, Health, at 8,13 . Indeed, a recent comprehensive national survey on illicit drug use found that 13 million Americans, or $6.2 \%$ of the population, use illicit drugs. See Marijuana Use By Teens Rises Sharply, WASH. POST, Sept. 13, 1995, at A8; see also Vital Statistics: Impact of Alcohol on American Lives, WASH. POST, Dec. 17, 1991, Health, at 5 (discussing a study conducted by the National Center for Health Statistics that found that $43 \%$ of the 177 million adults over age 18 were found to have been exposed to alcoholism in some way); $c f$. NORMAN K. DENZIN, THE RECOVERING ALCOHOLIC 17 (1987) (noting that in 1985 Alcoholics Anonymous counted a worldwide membership of over 1.2 million persons). But cf. KENNETH J. MEIER, THE POLITICS OF SIN: DRUGS, AlCOHOL AND PUBlic POLICY 105 (1994) (discussing alternative methods of measuring drug usage and the difficulty of obtaining reliable results). 
Addiction unquestionably places a tremendous strain on our communities. Crime and drug dependence seem inextricably linked. ${ }^{25}$ Substance abuse drains public resources and causes diminished workforce productivity. ${ }^{26}$ Furthermore, the correlation between substance abuse and public welfare problems is sufficiently profound to warrant aggressive policy action.

Additional socioeconomic ramifications of drug and alcohol use are equally profound. First, substance abuse jeopardizes both physical and mental health, ${ }^{27}$ resulting in a more fragile population and contributing to rising health-care costs. ${ }^{28}$ Second, addiction

${ }^{25}$ Homicide, assault, theft, and child abuse and neglect are all closely connected to drug use. See, e.g., 1 COMMITTEE FOR THE SUBSTANCE ABUSE Coverage STUDY, INSTITUTE OF MEDICINE, TREATING DRUG Problems 102 (Dean R. Gerstein \& Henrick J. Harwood eds., 1990) (conservatively estimating that in 19869 million crimes, causing $\$ 1.7$ billion in personal losses and $\$ 2.6$ billion in property losses, were attributable to the drug abuse of the offenders); Rich Connell, The Hidden Devastation of Crack, L.A. Times, Dec. 18, 1994, at A1, A18-A20 (citing an extensive array of recent statistics indicating greater incidence of random violence, high rates of arrest for drug possession, overcrowding of jails, and an increase in public costs for the maintenance of the children of crack addicts); see also Jiang Yu \& William $R$. Williford, Alcohol, Other Drugs and Criminality: A Structural Analysis, 20 AM. J. DRUG \& ALCOHOL ABUSE 373, 388 (1994) (finding that alcohol and cocaine use tends to increase involvement in criminal activities). See generally MICHAEL D. LYMAN, NARCOTICS AND CRIME CONTROL 159 (1987) ("It is no secret that a definitive, but complex correlation exists between drug crimes and other types of crime.").

${ }^{26}$ See, e.g., Marci M. DeLancey, Creating a Successful Drug-Free Workplace Program, EMPLOYMENT REL. TODAY, June 22, 1995, at 53, 53 (reporting that the annual cost of drug abuse to the business community is estimated to exceed $\$ 75$ billion, with losses in productivity alone amounting to $\$ 7.2$ billion for drug abuse and $\$ 33$ billion for alcohol abuse (citing MARCI M. DELANCEY, INSTITUTE FOR A DRUG-FREE WORKPLACE, DOES DRUG TESTING WORK? (1994))), available in LEXIS, News Library, Curnws File; see also 1 COMmTTEE FOR THE SUBSTANCE ABUSE COVERAGE STUDY, supra note 25, at 103 ("Crime career and incarceration losses to the economy were $\$ 12.2$ and $\$ 5.4$ billion in 1986, which arise from significant commitments to crime career endeavors by 1.1 million persons and the incarceration of 200,000 persons on drug charges or drug-related offenses." (citation omitted)); id. (suggesting that the largest cost attributable to drug abuse may be reduced productivity among the work force, although acknowledging the complexity of making such estimates).

${ }^{27}$ See Charles B. RaNGel, House Select Comm. ON Narcotics Abuse and CONTROL, 102D CONG., 2D SESS., ON THE EDGE OF THE AMERICAN DREAM: A SOCIAL AND ECONOMIC PROFILE IN 1992, at 1-2 (Comm. Print 1992) (stating that drug-related emergencies in hospitals increased from $26 \%$ to $31 \%$ ); William Claiborne, Substance Abusers Among Welfare's Young Mothers, WASH. POST, June 28, 1994, at A3 (citing a report by Columbia University's Center on Addiction and Substance Abuse that estimated "that Medicaid inpatient hospital costs of birth complications due to substance abuse could reach $\$ 4$ billion [in 1994]"); see also Mitchell S. Rosenthal, The Therapeutic Community: Exploring the Boundaries, 84 BRIT. J. ADDICTION 141, 148 (1989) (discussing increasing evidence of drug use among psychiatric admissions).

${ }^{28}$ See, e.g., Connell, supra note 25, at A18-A20 (estimating that treatment of 
and homelessness are closely connected. ${ }^{29}$ Third, substance abuse encourages dependency in other ways, including dependency on other people and on public benefits programs. ${ }^{30}$ Finally, on a less tangible level, drug and alcohol addiction signifies a loss of traditional values ${ }^{31}$ and perpetuates a deep-seated sense of widespread social disorder. ${ }^{32}$

A distinct lack of adequate, effective rehabilitation programs exacerbates the enormity of the substance abuse problem. Although one recent estimate by experts suggests that approximately twentythree million Americans require treatment for drug and alcohol abuse, our nation can treat only 800,000 annually. ${ }^{33}$ Among the

prenatal crack exposure can cost $\$ 8000$ to $\$ 20,000$ in the least severe cases and estimating the cost for the treatment of one premature crack baby at $\$ 75,000$ to $\$ 100,000)$.

${ }^{29}$ A 1988 survey of Oxford House residents found that nearly $40 \%$ reported that they had been homeless, half of whom had been homeless for periods of six months or more. See MOLloY, supra note 4 , app. G at 3 . In another survey, $68 \%$ of homeless men and $32 \%$ to $38 \%$ of homeless women surveyed were found to be probable or definite alcoholics. See William R. Breakey et al., Health and Mental Health Problems of Homeless Men and Women in Baltimore, 262 JAMA 1352, 1355 (1989). Although the statistics were somewhat lower for narcotic addiction, one additional inquiry found that more than half of the subjects had used drugs at least occasionally and that $22 \%$ of homeless men and $17 \%$ of homeless women qualified as drug abusers. See id. This same survey also identified $56 \%$ of men and $17 \%$ of women as having alcoholdependence syndrome, a more severe condition. See id.

${ }^{\text {so }}$ See, e.g., Connell, supra note 25, at A19 (describing one woman's dependence on publicly funded drug treatment centers and state-run foster care services).

${ }^{31}$ See, e.g., Sam H. Verhovek, Powell Deftly Deflecting Questions on Presidency, N.Y. TIMEs, Feb. 1, 1995, at A12 (quoting General Colin Powell as saying that he believes that most social ills, including drug abuse, are caused by a lack of traditional family values); see also Kathy Lauer-Williams, Action Against Drug Abuse Urged, MORNING CALL (Allentown), June 20,1995, at B5 (quoting the Executive Director of the Philadelphia Anti-Drug, Anti-Violence Network as citing the lack of spiritual and family values as part of the reason for increasing substance abuse), available in LEXIS, News Library, Curnws File.

${ }^{32}$ See Rosenthal, supra note 27 , at $147-48$ ("Drug abuse is plainly both a cause and an effect of widespread social disorder. ... Where there is drug abuse, there is invariably other disordered behavior. Where other disordered behavior exists, so does drug abuse.").

ss See Trafford, supra note 24, at 13; see also Gina Kolata, Twins of the Streets: Homelessness and Addiction, N.Y. TIMES, May 22, 1989, at A1 (noting that in 1989, there were 50,000 to 100,000 homeless people in Los Angeles County but only 20 or 25 beds available to them in residential treatment programs and describing an addict's experience of trying to get clean only to receive the 397 th slot on a waiting list for a program); Elizabeth Shogren, Cisneros Asks Stronger Federal, Private Efforts to Aid U.S. Homeless, L.A. TIMES, Dec. 2, 1993, at A7 (citing a shortage of drug treatment facilities as a reason for homelessness). See generally 1 COMMITIEE FOR THE SUBSTANCE ABUSE COVERAGE STUDY, supra note 25, at 76-104 (studying the need for drug treatment in the criminal justice system and among household and homeless 
general population of addicts, eighty percent of those in treatment relapse. In contrast, those who live in group homes for recovering substance abusers are highly likely to achieve their goal of sobriety. Among group home residents, eighty percent remain clean and sober. ${ }^{34}$

Residential treatment significantly reduces the incidence of crime and other social ills. ${ }^{35}$ It may, in fact, save money by reducing the social costs of drug use. One expert recently testified before a Senate Committee that

[v]irtually all economic measures show that the burden of crime and other economic consequences of drug abuse are lower after treatment than before. Costs of drug abuse to law abiding citizens

populations in the years 1987 and 1988).

94 See Fair Housing: Testimony Before the Subcomm. on Civil and Constitutional Rights of the House of Representatives Comm. on Judiciary, 104th Cong., 2d Sess. (1994) (statement of J. Paul Molloy, Chief Executive Officer, Oxford House, Inc.), available in Westlaw, USTestimony database, 1994 WL 530652 [hereinafter Fair Housing Testimony]; see also William H. Spillane \& Dean F. Ahern, Catholic University of America, Final Report: Developmental Exploratory Study of Six Newly Formed Group Recovery Homes 55 (Feb. 15, 1991), cited in Herbert A. Eastman, War on Drugs or on Drug Users? Drug Treatment and the NIMBY Syndrome, 5 B.U. PUB. INT. L.J. 15, 29 n.23 (1994).

${ }^{35}$ See Michael T. French et al., The Effects of Time in Drug Abuse Treatment and Employment on Postreatment Drug Use and Criminal Activity, 19 AM. J. DRUG \& ALCOHOL ABUSE 19, 31 (1993) (finding a "negative, statistically significant, and stable effect on Posttreatment Drug Use and Criminal Behavior Indexes" for individuals enrolled in the treatment); $i d$. (finding in the same study "that residential clients always showed the greatest relative improvement in drug use and criminal activity from additional time in treatment ${ }^{n}$ ).

In one recent study, the California Department of Alcohol and Drug Programs followed more than 1800 people discharged from treatment programs in California between October 1991 and September 1992, a population carefully selected to represent a cross section of the 150,000 people who received treatment that year in California. Researchers concluded that substance abuse treatment programs do help to reduce crime and lower health-care costs, saving taxpayers millions of dollars. For the $\$ 209$ million that state residents invested in chemical dependency treatment during the year, taxpayers saved approximately $\$ 1.5$ billion-a return of seven dollars for every one dollar spent in treatment. See Daniel J. Anderson, Savings Outweigh Treatment Costs, STAR TRIB. (Minneapolis), Mar. 14, 1995, at 7E; Michael Darcy, Push Treatment, CHI. TRIB., Sept. 13, 1994, § 1, at 12 (discussing the California study and reporting that in 1994 treatment cost $\$ 2234$ per person, whereas one year of incarceration cost $\$ 39,600$ and one year of untreated addiction cost $\$ 43,200$ ); see also Larry Gostin, The Interconnected Epidemics of Drug Dependency and AIDS, 26 HARV. C.R.-C.L. L. REv. 113, 164-66, 175 (1991) (describing how effective treatment of alcohol and drug abuse improves psychological adjustment, increases employment, and reduces crime and other forms of antisocial behavior (citing V. TABBUSH, THE EFFECTIVENESS AND EFFicienCy OF PUBlicly Funded DRUG ABUSE TREATMENT AND Prevention Programs in California: A Benefit Cost Analysis (1986))). 
fall by about $20 \%$, costs to victims decline by about $30 \%$, criminal justice costs fall about $24 \%$ and the costs of theft fall about $11 \% .^{36}$

These statistics provide only a glimmer of the cost-effectiveness of community living programs for drug addicts and alcoholics. First, group homes for recovering substance abusers do not cost the federal government much money. A typical project receives one small, short-term, start-up loan from the federal government, amounting to no more than $\$ 4000 .^{37}$ Thereafter, it remains a wholly self-run, self-supporting entity. ${ }^{38}$ Second, such programs address the continued plight of homelessness. The link between substance abuse and homelessness cannot be underestimated. In Philadelphia, for example, a recent survey found that eighty to ninety percent of homeless single adults are addicted to drugs or

${ }^{36}$ Capitol Hill Hearing Testimony: Ellen M. Weber Co-Director of National Policy Legal Action Center Senate Labor Substance Abuse and Mental Health Services Administration Reauthorization, Federal Document Clearing House Congressional Testimony, July 27, 1995, available in LEXIS, Legis Library, Cngtst File; see also id. (noting that "on average, untreated alcoholics incur general health-care costs that are at least $100 \%$ higher than those of nonalcoholics," but that treatment of addiction reduces days lost to illness, sickness claims, and hospitalizations by approximately 50\%); Capitol Hill Hearing Testimony: Hon. Lee P. Brown Director Office of National Drug Control Policy House Appropriations Treasury, Postal Service and General Government FY96 Treasury, Postal Appropriations, Federal Document Clearing House Congressional Testimony, Mar. 28, 1995 (discussing a 1994 study of drug treatment in California that found that every dollar spent on drug treatment translates into seven dollars saved in crime and healthcare costs), available in LEXIS, Legis Library, Cngtst File.

A similar study found that for 10,000 individuals receiving addiction treatment during a five-year period, treatment returned to society almost the entire financial outlay: the costs to society were reduced by $8 \%$; the costs to victims of drug-related crime were reduced by about $30 \%$; the costs to the criminal justice system were reduced by about $24 \%$; and the costs to victims of theft were reduced by $11 \%$. See John E. Franklin et al., Barriers to the Implementation of a Program for Inner-City, Homeless Substance Abusers on General Assistance: Newark, ALCOHOLISM TREATMENT Q., No. 3/4, 1993, at 65, 66 (citing R. Hubbard et Al., Drug AbuSE Treatment: A NATIONAL STUDY OF EFFECTIVENESS (1989)).

${ }^{37}$ See 42 U.S.C. \$ 300x-25(a)(4) (Supp. V 1993).

${ }^{38}$ See, e.g., 137 CONG. REC. S5998-99 (daily ed. May 16, 1991) (statement of Sen. Cranston) (explaining that a group home for veterans with mental disabilities and substance abuse problems would be inexpensive because the program, after start-up costs, would be paid for by the patients involved through their work under contracts that the Veterans' Administration would make with outside businesses). 
alcohol..$^{39}$ Nationally, forty-three percent of the urban homeless are substance abusers. ${ }^{40}$

Safe, affordable housing in drug-free environments is difficult to find, and often nonexistent. ${ }^{41}$ Experts have noted that although drug-free housing is an essential component of any effective drug treatment program, "[o]ne of the chief obstacles to successful community care of individuals . . . has been the lack of adequate, affordable housing. ${ }^{n 2}$ Indeed, it is more difficult for recovering substance abusers to find adequate housing in drug- and alcoholfree environments after a rehabilitation program than it is to get into a rehabilitation program itself. ${ }^{49}$ In light of this housing shortage for recovering addicts and the massive potential costs exacted by continued substance abuse and future treatment, supporting programs that provide less expensive, more effective rehabilitation is even more important. ${ }^{44}$

${ }^{39}$ See Steven R. Paisner, Comment, Compassion, Politics, and the Problems Lying on Our Sidewalks: A Legislative Approach for Cities to Address Homelessness, 67 TEMP. L. REv. 1259, 1266 n.49 (1994) (citing Don Klingerman, Fairmount Capital Advisors, Presentation to the Mayor's Commission on Homelessness, City of Philadelphia (May 20, 1993)).

${ }^{10}$ See Bruce Alpert, Morial: Homeless on Rise in N.O., TIMEs-PiCAYUNE (New Orleans), Dec. 20, 1994, at B1 (discussing the first report by the U.S. Conference of Mayors on hunger and homelessness in America).

${ }^{11}$ See Brian E. Mavis et al., Treatment Needs and Outcomes of Two Subtypes of Homeless Persons Who Abuse Substances, 44 HOSP. \& COMMUNITY PSYCHIATRY 1185, 1185-87 (1993) (comparing housed and homeless substance abusers, finding that the problems of the homeless clients were more pervasive, chronic, and severe, and suggesting that supportive housing may help prevent clients from returning to the streets and resuming their drug habits).

12 Otto F. Wahl, Community Impact of Group Homes for Mentally Ill Adults, 29 COMMUNITY MENTAL HEALTH J. 247, 248 (1993) (noting that this is especially true for people living on disability incomes who often "find themselves limited to run-down apartments in the most crime-ridden, pest infested parts of their cities, to barren overcrowded shelters, or to the streets as part of ... "the homeless" (citation omitted)); $c f$. Frances L. RANDOLPH ET AL., IN SEARCH OF Housing: CREATIVE APPROACHES TO FINANCING INTEGRATED HOUSING 1-2, 5 (1987) (finding that despite a widespread recognition of homelessness among those persons with psychiatric disabilities, one of the largest gaps in community support systems is the lack of affordable housing that is available on a long-term basis and that is linked to services and supports).

4s See Brief for American Association on Mental Retardation and Other Groups Listed on Inside Cover As Amici Curiae in Support of Respondents pt. IV.A, City of Edmonds v. Oxford House, Inc., 115 S. Ct. 1776 (1995) (No. 94-23), available in LEXIS, Genfed Library, Briefs File.

14 See James M. Raczynski et al., Comparing Two Substance Abuse Treatments for the Homeless: The Birmingham Project, ALCOHOLISM TREATMENT Q., No. 3/4, 1993, at 217, 231 (describing how drug-free housing not only creates suitable homes, but provides greater opportunity for vocational training and paid work experience, provides a 


\section{B. How Group Homes for Recovering Substance Abusers Work}

The theory behind group homes for recovering substance abusers is simple: "[A]ddicted individuals can help themselves by helping each other abstain from alcohol and drug use one day at a time for a long enough time to permit a new set of values to be substituted for the values of a lifestyle in which alcohol and drugs were used. ${ }^{n 5}$ Programs that use this model work because the environment that they provide balances the needs for constant support, community integration, and independence. ${ }^{46}$

The therapeutic aspects of the group-home concept are indeed manifold, providing the basis for successful treatment and the resources for self-reliance. At the core of this model is the fundamental notion that initial treatment, frequently referred to as "detox," is not the end but the beginning of the alcoholic's or drug addict's recovery. ${ }^{47}$ Substance abusers frequently lack the independent living skills, communication abilities sense of responsibility, self-esteem, and independence necessary to make it on their own. ${ }^{48}$

source of immediate success experience that serves to increase self-esteem, and rewards people who continue their recovery, because only those who remain drugfree are eligible for housing).

${ }^{45}$ MOLLOY, supra note 4, at 7; see also id. at 8 ("The basic idea [is] that one addict is a primary source of help for another ....").

${ }_{46}$ See $i d$. at 8.

${ }^{47}$ As one court has commented:

[A]lcoholism and drug addiction place severe limitations on people's lives, including disrupting personal relationships, and impairing one's ability to advance in education or employment, and ... such limitations do not magically disappear at the moment that abstinence begins, but rather continue to effect a person's functioning at least through the early stages of recovery. It is because of these limitations that recovering drug addicts and alcoholics need to live in a supportive environment of the type that Oxford House provides. Many witnesses testified as to the crucial importance of this supportive and drug-free environment in ensuring that a recovering alcoholic or addict does not relapse.

Oxford House, Inc. v. Township of Cherry Hill, 799 F. Supp. 450, 460 (D.N.J. 1992).

${ }^{48}$ See, e.g., Molly Kavanaugh, Home Offers Hope for Drug-Free Life, PLAIN DEALER (Lorain, Ohio), Jan. 4, 1993, at 4B (describing one resident's first independent shopping excursion since ending her drug addiction and her sense of pride from this small but important achievement); id. ("Being here is teaching me to grow up."); see also Oxford House-C v. City of St. Louis, 843 F. Supp. 1556, 1563 (E.D. Mo. 1994) (noting that "alcoholics and drug abusers frequently have lost contact with their families or mainstream society prior to their recovery, and may lack or have lost basic life skills such as budgeting, arriving at work on time, maintaining employment, cooperating with family members, and managing their own lives"). 
In a group home, they are provided with the time, tools, and support to acquire these things.

Recovery houses promote both treatment and self-reliance. On the treatment side, this type of housing diminishes social stress and provides a therapeutic community. ${ }^{49}$ Residents share not only the same living space, but make decisions together, help each other find work, and furnish support. ${ }^{50}$ From a self-reliance perspective, the group-home model relies less on the help of trained professionals, thereby decreasing the recovering addict's role as a patient; it focuses on normalization rather than on deviance; and it provides a recovering substance abuser with the opportunity to obtain greater control over his or her own environment. ${ }^{51}$ Fundamentally, group homes for recovering substance abusers are entities based upon faith in, and trust of, their members. ${ }^{52}$ This in turn fosters pride and self-esteem, traits often not readily found among alcoholics and drug abusers. ${ }^{53}$ The benefits of this cooperative living format make it essential to allow recovering substance abusers to live together.

Merely providing a group setting, however, is not enough. Housing must be located in appropriate communities for drug and

${ }^{19}$ See Beny J. Primm, Foreword to Molloy, supra note 4 ("Recovery from the disease of alcoholism or other drug addiction is often plagued by relapse .... The self-run, self-supported recovery house provides many recovering individuals effective relapse prevention because of . . . the support gained from living with other individuals coping with the same problem ... ."); see also Paula Goering et al., Social Networks of Residents in Supportive Housing, 28 COMMUNITY MENTAL HEALTH J. 199, 212 (1992) (finding that living in supportive housing arrangements has a positive influence on residents' social networks); Michael F. Hogan \& Paul J. Carling, Normal Housing: $A$ Key Element of a Supported Housing Approach for People with Psychiatric Disabilities, 28 COMMUNITY MENTAL HEALTH J. 215, 222 (1992) (explaining that a stable, positive quality of life keeps stress levels manageable and facilitates a positive, stable lifestyle).

${ }^{50}$ See 137 ConG. REC. S6000 (daily ed. May 16, 1991) (statement of Sen. Cranston) (noting that the group home structure allows "individuals in recovery the opportunity to determine their own living environments; .. . [provides] a supportive environment free of alcohol or drug use; and ... reinstills pride and self-esteem").

51 For example, recovery houses usually recommend participation in other selfhelp programs such as Alcoholics Anonymous ("AA") or Narcotics Anonymous $\left({ }^{\prime N A}{ }^{n}\right.$ ). See MOLLOY, supra note 4, at 26-27 (noting that although Oxford Houses do not hold AA or NA meetings on the premises, members tend to average about six meetings each week). See generally Hogan \& Carling, supra note 49, at 216 (criticizing the overemphasis on "special needs" and encouraging integrated, supported housing); Kenneth L. Robey, Group Home Residents' Identities As Patients and As Community Members, 45 Hosp. \& CoMmUNITY PsYCHIATRY 58, 58 (1994) (studying group-home residents' self-identification as patients and community members).

${ }^{52}$ See 137 CoNG. REC., supra note 50, at $\mathbf{5 9 9 9 .}$

${ }^{53}$ See id. at $\mathbf{S 6 0 0 0 .}$ 
alcohol rehabilitation to succeed. This is essential for many reasons. First, because recovering substance abusers are trying to reintegrate into society, it is important that they be treated no differently than "mainstream" community members. Recognizing that former addicts have the same concerns as others who seek housing is therefore imperative. Like anyone looking for a new place to live, a person in recovery wants a home, not merely housing. A former addict wants self-determination, the opportunity to decide for herself where to live. ${ }^{54}$ This choice not only promotes dignity, it also fosters responsibility and independence, thereby furthering the former addict's rehabilitation.

Second, living in single-family areas has been found to be a necessary component of group housing for former drug addicts and alcoholics. Fear resulting from decreased safety and poor living conditions as well as social isolation hinders recovery; ${ }^{55}$ whereas proximity to public transportation, employment, recreational opportunities, and shopping directly promotes it. ${ }^{56}$ Recent studies repeatedly indicate that the better the neighborhood, the better the chances that addicts will recover. A United States General Accounting Office survey found that safe, stable neighborhoods with high percentages of single-family residences create the best opportunity for recovery. ${ }^{57}$ Likewise, middle- to higher-income communities improve the chances of social adjustment, more effectively promote community integration, and provide better resources. ${ }^{58}$ As one

${ }^{54}$ This is the position advocated by proponents of "supported housing." "People should be given the opportunity to actively participate in the selection of their housing arrangements from among those living environments available to the general public." Hogan \& Carling, supra note 49, at 216 (quoting the National Association of State Mental Health Program Directors' position statement on housing and support for people with long-term mental illness).

55 People who live in isolated or poor neighborhoods with high crime rates generally have little contact with their community. See Martin Jaffe \& Thomas P. Smith, Siting Group Homes for Developmentally Disabled Persons 8 (1986). Furthermore, it is extraordinarily difficult, if not altogether impossible for group-home residents to create a proper home life when they are forced to live in commercial or industrial neighborhoods. See Daniel Lauber \& Frank S. Bangs, Jr., American Society of Planning Officials, Zoning for Family and Group Care Facilities 8, 10 (Mar. 1974).

${ }^{56}$ See Hogan \& Carling, supra note 49, at 224 ("A housing location proximate to public transportation, employment, recreational opportunities . . . and so forth will make it easier for consumers to control and direct these aspects of their lives. These opportunities for control facilitate learning of practical living skills, and may reduce dependency ....").

${ }^{57}$ See U.S. Gen. Accounting Office, AN ANALYSis OF ZONING AND OTHER

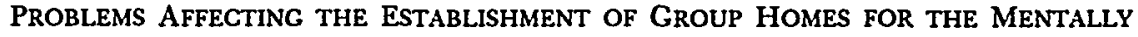
DISABLED app. at 8 (1983).

${ }^{58}$ See John T. Hull \& Joy C. Thompson, Factors Which Contribute to Normalization 
expert noted, "the prevailing opinion among alcohol and drug professionals [is] that the key to successful treatment is to provide social and physical environments where sobriety is positively valued."59 Furthermore, because group homes play an essential role in recovering addicts' reintegration into society and redevelopment of self-sufficiency, these homes must not be isolated from mainstream society. ${ }^{60}$ Thus, siting group homes for recovering substance abusers in single-family residential areas not only increases self-esteem and independence, but also promotes integration, thereby decreasing the potential for relapse.

The Oxford House organization best illustrates how the theory of group homes can effectively be put into practice. ${ }^{61}$ It is not only the most widespread recovery house program, but it is also tremendously successful. The national organization began with one house in 1975, when a group of recovering alcoholics were faced with the closing of their county-supported halfway house. Since then, the organization has grown to more than 526 homes, located in thirty-seven states and the District of Columbia, and has helped more than 20,000 individuals on the road to remaining clean and sober. ${ }^{62}$

There is no typical Oxford House resident. ${ }^{63}$ Participants in the program include men and women, young and old, black and

in Residential Facilities for the Mentally Ill, 17 COMMUNITY MENTAL HEALTH J. 107, 111 (1981); see also Frank Baker \& Charlene Douglas, Housing Environments and Community Adjustment of Severely Mentally Ill Persons, 26 COMMUNITY MENTAL HEALTH J. 497, 50304 (1990) (noting the "importance of the relationship between the quality and appropriateness of housing and the clients' level of functioning").

59 James D. Wright et al., The New Orleans Homeless Substance Abusers Program, AlCoHolism TREATMENT Q., No. 3/4, 1993, at 51, 53; cf. Baker \& Douglas, supra note 58, at 503 (arguing that when people with severe mental illness live in housing that is physically unappealing and which by all accounts is "inappropriate," their degree of maladaptive behavior also increases); Jean T. Turner \& Thomas T.H. Wan, Recidivism and Mental Illness: The Role of Communilies, 29 COMMUNITY MENTAL HEALTH J. 3, 11 (1993) (finding that living in low socioeconomic status community is inversely correlated with recidivism for mentally ill patients).

${ }^{60}$ See Oxford House-C v. City of St. Louis, 843 F. Supp. 1556, 1564 (E.D. Mo. 1994) (commenting that these houses should not be isolated in industrial neighborhoods).

${ }^{61}$ See generally United States v. Borough of Audubon, 797 F. Supp. 353, 355 (D.N.J. 1991) (providing a brief history of Oxford Houses and contextualizing their significant role in substance abuse rehabilitation), affd, 968 F.2d 14 (3d Cir. 1992).

${ }^{62}$ See Fair Housing Testimony, supra note 34 (noting that more than 5000 recovering individuals currently live in Oxford Houses).

6s See, e.g., United States v. Village of Palatine, No. 93 C 2154, 1993 WL 586699, at *3-6 (N.D. Ill. Sept. 28, 1993) (offering personal stories of some Oxford House residents), vacated and remanded, 37 F.3d 1230 (7th Cir. 1994). 
white, rich and poor, well-educated and uneducated. ${ }^{64}$ The average length of stay in an Oxford House is fifteen months. ${ }^{65}$ Some participants, however, stay with the program only a short time, whereas others remain significantly longer. ${ }^{66}$ Although the goals of Oxford House may be lofty and its population diverse, the program's rules are straightforward: Participating homes must be run democratically; they must be financially self-supporting; and they must immediately expel anyone who uses drugs or alcohol. ${ }^{67}$ This supportive program with stringent rules has become a national model. Legislators describe it as the "missing link' in the treatment process for alcoholism and drug addiction," it as a "nationally recognized program which, through peer pressure and strict conditions of abstinence, successfully maintains freedom from addiction and improves the lives and opportunities of its participants." $" 69$

Congress has twice enacted legislation encouraging the development of Oxford Houses and similarly modeled programs with the Anti-Drug Abuse Act of $1988^{70}$ and the ADAMHA Reorganization Act. ${ }^{71}$ Indeed, the Group Homes for Recovering Substance

${ }^{64}$ In terms of age composition, $29 \%$ of Oxford House residents are young adults between the ages of 18 and $29,41 \%$ are between the ages of 29 and 39 , and $30 \%$ are older adults. See MOLLOY, supra note 4, app. G at 1. In terms of race, Oxford House residents are almost all primarily white or black, and they are almost equally divided between these two categories. See id. In terms of education, a 1988 survey found that approximately $80 \%$ of Oxford House residents have graduated from high school and more than $30 \%$ have completed some college work. See id. at 2; see also An Oxford Home Remedy, ST. LOUIS POST-DISPATCH, Nov. 8, 1994, at 10B (providing 1988 statistics on the racial composition of program residents and noting that Oxford Houses are not coed, but rather provide separate houses for women and men).

${ }^{65}$ See Carey Q. Gelernter, Oxford House: Sober to Stay, SEATtLe Times, Apr. 17, 1994, at M1, M5.

${ }_{66}^{6}$ See, e.g., William H. Freivogel, West Coast Case to Affect Oxford House Havens Here, ST. LOUIS POST-DISPATCH, Mar. 2, 1995, at 5B (describing the experiences of one member who had been a resident of Oxford House for $31 / 2$ years); cf. MOLLOY, supra note 4, app. $G$ at 4-5 (summarizing the results of a 1988 Oxford House survey in which fewer than $25 \%$ of the members had been residents for less than four months).

${ }^{67}$ See MOLlOY, supra note 4, app. C at 19 (listing "Oxford House Traditions"); see also Mitra, supra note 1, at 1 (detailing the rationale of Oxford Houses).

${ }^{68} 134$ CoNG. REC. E3733 (daily ed. Nov. 10, 1988) (statement of Rep. Madigan).

${ }^{69}$ Oxford House-Evergreen v. City of Plainfield, 769 F. Supp. 1329, 1331 (D.N.J. 1991).

${ }^{70}$ See Pub. L. No. 100-690, sec. 2036, $\$ 1916$ A, 102 Stat. 4181, 4202-03 (codified at 42 U.S.C. $\$ 300 \mathrm{x}-4 \mathrm{a}(1988)$ ) (establishing a program entitled Group Homes for Recovering Substance Abusers) (repealed 1992 and superseded by 42 U.S.C. $\S 300 x-$ 25 (Supp. V 1993)).

${ }^{7}$ Pub. L. No. 102-321, sec. 202, § 1925, 106 Stat. 323, 393-94 (1992) (codified at 
Abusers Program ${ }^{72}$ was an integral part of President Reagan's War on Drugs. ${ }^{73}$ The government has described this legislation as providing for a "nationwide establishment of self-help recovery housing services and a cost-effective method for many recovering individuals to avoid relapse. ${ }^{74}$ With the passage of the Anti-Drug Abuse Act of 1988, each state became obligated to encourage the development of such programs and to establish revolving loan funds of at least $\$ 100,000$ to mitigate group-home start-up costs. ${ }^{75}$ States failing to comply with the legislation can lose their eligibility for all federal block grants for drug and alcohol treatment. ${ }^{76}$

The timing of the passage of the Anti-Drug Abuse Act is particularly noteworthy. ${ }^{77}$ Within months of its signing, the very same group of legislators passed the FHAA. ${ }^{78}$ Through the enactment of these two laws, Congress articulated a strong, clear public policy opposing housing discrimination on the basis of disability and supporting the establishment of group housing for recovering drug addicts and alcoholics. ${ }^{79}$ Courts have recognized the inextricable link between these two policies. The Anti-Drug

42 U.S.C. $\$ 300 x-25$ (Supp. V 1993)) (reenacting the Group Homes for Recovering Substance Abusers program).

The rules for recovery house programs established under the Act track the same, simple, stringent rules established by Oxford House: Group homes receiving revolving loan funds must be nonprofit entities that have at least six residents; they must prohibit the use of alcohol and illegal drugs on the premises; and they must immediately expel any person who violates this rule. See id.

${ }_{72}$ See 42 U.S.C. $\$ 300 x-4 a$ (current version at 42 U.S.C. $\$ 300 x-25$ (Supp. V 1993)).

${ }^{73}$ See Fair Housing Testimony, supra note 34 (describing how President Reagan's drug advisor, Dr. Ian MacDonald, was sent to visit one of the D.C. Oxford Houses); see also Lawmakers, supra note 23, at 3 (describing the group-home initiative as "one of the most important initiatives to result from the Anti-Drug Abuse Act of 1988" (quoting a joint letter written to former Secretary of Health and Human Services, Louis Sullivan, by Congressmen Dingell, Lent, Waxman, and Madigan)).

${ }^{71}$ Group Home for Recovering Substance Abusers; Guidelines, 54 Fed. Reg. $15,807,15,808$ (1989).

${ }_{75}$ See sec. $2036(\mathrm{a})(3), \S 1916 \mathrm{~A}, 102$ Stat. at 4202 (codified at 42 U.S.C. $\S 300 \mathrm{x}$ $4 a(a)(3))$.

${ }^{76}$ See sec. $2036($ a), $\S 1916 \mathrm{~A}(\mathrm{a}), 102$ Stat. at 4202 (codified at 42 U.S.C. $\S 300 \mathrm{x}-$ $4 a(a))$.

77 President Reagan signed the legislation on September 13, 1988, to encourage expansion of the Oxford House model. See Remarks on Signing the Fair Housing Amendments Act of 1988, Pub. PAPERS 1155 (Sept. 13, 1988).

${ }^{78}$ Fair Housing Amendments Act of 1988, Pub. L. No. 100-430, 102 Stat. 1619 (codified at 42 U.S.C. $\$ \S 3602,3604-3631$ (1988)).

${ }^{79}$ See MOLLOY, supra note 4, app. B ("The Fair Housing Act Amendments of 1988 facilitate the national goal to mass replicate the cost-effective missing link Oxford House brings to the process of recovery from addiction to alcohol and drugs."). 
Abuse Act of 1988 and the merits of group homes are discussed in numerous decisions that employ the FHAA to protect the housing rights of recovering drug addicts and alcoholics. ${ }^{80}$ As one court commented:

Through its enactment of the Fair Housing Amendments of 1988 and the Federal Anti-Drug Abuse Act of 1988, Congress has expressed a strong public policy favoring ... the establishment of housing programs for recovering drug addicts and alcoholics. Indeed, the Anti-Drug Abuse Act's provision encouraging the establishment of revolving loan funds by states to make start-up loans to help establish group homes for recovering drug addicts and alcoholics was based specifically on the model of Oxford House. Thus, Congress has directly endorsed Oxford House itself as an organization worthy of public support because of its role in helping to stem the national epidemic of alcohol and drug abuse. $^{81}$

\section{The Housing Rights of Recovering Substance Abusers AND THE FAIR HOUSING AMENDMENTS ACT OF 1988}

Congress enacted the FHAA in large part to prohibit housing discrimination against people with disabilities. ${ }^{82}$ The law was designed to achieve two purposes: (1) to end the prejudice and stereotyping directed toward people who have mental, physical, or emotional impairments; and, (2) to integrate effectively this traditionally excluded population into mainstream society. ${ }^{83}$

${ }^{80}$ See, e.g., Oxford House, Inc. v. Township of Cherry Hill, 799 F. Supp. 450, 465 (D.N.J. 1992) (concluding that the court would be "hard pressed to deny the significance of the public interest in supporting efforts like Oxford House" in the face of the "clear expressions of legislative support for the goal of reducing drug addiction and alcoholism" set forth in the Anti-Drug Abuse Act of 1988 and the FHAA); see also United States v. Village of Palatine, No. 93 C 2154, 1993 WL 586699, at *3 (N.D. Ill. Sept. 28, 1993) (stating that, in accordance with the Anti-Drug Abuse Act, "[s]uch houses provide an environment in which residents 'may either relearn or learn basic life skills, responsibilities that they may not have had before, in a supportive situation with other people who are of similar character" (quoting trial transcript)).

81 Township of Cherry Hill, 799 F. Supp. at 465 (citation omitted).

82 The FHAA addresses not only discrimination against people with disabilities, it also prohibits discrimination based on family status, see 42 U.S.C. $\$ \S 3604-3606$, and strengthens the government's ability to enforce the Act's provisions, see 42 U.S.C. $\S \S 3610-3614$.

${ }^{83}$ See H.R. REP. No. 711, 100th Cong., 2d Sess. 18 (1988), reprinted in 1988 U.S.C.C.A.N. 2173, 2179.

The Fair Housing Amendments Act . . . is a clear pronouncement of a national commitment to end the unnecessary exclusion of persons with handicaps from the American mainstream. It repudiates the use of stereo- 
Inclusive in scope and short on exceptions, ${ }^{84}$ the FHAA provides an expansive interpretation of the term "handicapped" ${ }^{85}$ and an array of methods to prove housing discrimination. ${ }^{86}$ Indeed, Congress intended that the FHAA establish a legislative framework capable of ending the unnecessary exclusion of former drug addicts and recovering alcoholics from communities of their choosing.

\section{A. The Purpose and Parameters of the FHAA}

With broad strokes, the 101 st Congress enacted a law to protect those who suffer from housing discrimination because of their mental, physical, or emotional disabilities. Recognizing the pervasiveness of and the damage caused by such bias, Congress passed the FHAA, ${ }^{87}$ which amended Title VIII of the Givil Rights Act, commonly known as the Fair Housing Act of $1968 .^{88} \mathrm{Al}-$ though the original legislation, passed in the wake of racial strife and urban unrest, ${ }^{89}$ decidedly prohibited discrimination on the basis of color, race, religion, national origin, and gender, ${ }^{90}$ the

types and ignorance, and mandates that persons with handicaps be considered as individuals. Generalized perceptions about disabilities and unfounded speculations about threats to safety are specifically rejected as grounds to justify exclusion.

Id.; see also Richard B. Simring, Note, The Impact of Federal Antidiscrimination Laws on Housing for People with Mental Disabilities, 59 GEO. WASH. L. REV. 413, 420 (1991) ("The FHAA seeks to achieve two goals: to secure to people with disabilities the right to establish a home free of discrimination in any community they choose, and to integrate people with handicaps into the mainstream of American life. "); infra notes 92-94 and accompanying text (describing congressional intent in passing the FHAA).

${ }^{8+}$ See infra parts II.A.1, II.C (describing the FHAA's broad definitions of "discrimination" and "handicap" and its narrow "direct threat" and "reasonable maximum occupancy" exceptions).

${ }^{85}$ See infra part II.A.2 (explaining how the FHAA affords protection to recovering substance abusers).

${ }^{86}$ See infra part II.B (delineating the "intentional act," "discriminatory effect," and "failure to reasonably accommodate" methods for proving housing discrimination).

${ }^{87}$ Pub. L. No. 100-430, 102 Stat. 1619 (codified at 42 U.S.C. $\$ \S 3602,3604-3631$ (1988)).

${ }_{88}$ Pub. L. No. 90-284, 82 Stat. 73 (codified as amended at 42 U.S.C. $\$ \$ 3601-3631$ (1988)).

${ }^{89}$ See Simring, supra note 83 , at $413 \mathrm{n} .4$ (noting that the original act was passed during the civil rights movement, following the assassination of Dr. Martin Luther King, J $\mathbf{r}$.).

90 See Fair Housing Act of $1968 \S \S 804-806,82$ Stat. at 83-84 (codified as amended at 42 U.S.C. $\$ \S 3604-3606$ ). The Fair Housing Act was amended in 1974 to ban housing discrimination on the basis of gender. See Housing and Community Development Act of 1974, Pub. L. No. 93-383, sec. 808(b)(1)-(3), \$\$ 804-806, 88 Stat. 633, 729 (codified as amended at 42 U.S.C. $\$ \S 3604-3606$ ). 
amended version went even further-it recognized that the civil rights of people with disabilities could be protected only by affording them equal housing opportunities. ${ }^{91}$

The FHAA's prohibition against handicapped discrimination was designed with two goals in mind: (1) to alter attitudes toward individuals with disabilities; ${ }^{92}$ and (2) to eradicate the manifestation of such stereotyping and bias-discrimination. ${ }^{93}$ By setting forth these goals, Congress intended to provide individuals with disabilities the opportunity to become more independent and to realize the full extent of their civil rights. The FHAA's general purpose was emphasized by those in Congress advocating its passage. Senator Alan Cranston noted:

Ensuring nondiscrimination in housing means ensuring an essential element of independence and integration into the community for disabled individuals. The right to vote, to work, and to travel freely are all important aspects of an individual's life, but none is more elementary than having the freedom to choose where and how one lives. Housing is shelter-but it is much more. It's the opportunity to be part of a community. ${ }^{94}$

\section{The FHAA Provides Expansive Protection}

To promote the civil rights of people with disabilities, the FHAA makes it unlawful to "discriminate in the sale or rental, or to otherwise make unavailable or deny, a dwelling to any buyer or renter because of a handicap." ${ }^{95}$ Such discrimination includes:

${ }^{91}$ See Fair Housing Amendments Act of 1988, sec. 6, $\$ 804-806,102$ Stat. at $1620-22$ (codified at 42 U.S.C. $\$ \$ 3604(f)(1), 3605(a), 3606)$.

${ }^{92}$ See H.R. REP. NO. 711, supra note 83 , at 1 ("Prohibiting discrimination against individuals with handicaps is a major step in changing the stereotypes that have served to exclude them from American life. These persons have been denied housing because of misperceptions, ignorance, and outright prejudice."), reprinted in 1988 U.S.C.C.A.N. 2173, 2179; see also Simring, supra note 83, at 413 (describing the Fair Housing Act and its 1988 amendments as laws designed "to alter people's attitudes toward individuals with disabilities and to lift barriers to integration that communities may put in their way").

${ }_{93}^{93}$ See 134 ConG. REC. S10,552 (daily ed. Aug. 2, 1988) (statement of Sen. Weicker) (arguing in support of the FHAA that " $[\mathrm{t}]$ he major barrier faced by people with disabilities today-discrimination-is not going to go away until we find ways to end their segregation and isolation from the rest of society").

It $I d$. at $\mathrm{S} 10,556$.

${ }^{95} 42$ U.S.C. $\$ 3604(f)(1)$. The amended act also established more stringent enforcement mechanisms for the Department of Housing and Urban Development (HUD), widely expanded its coverage to reach bias based on "familial" status, and eliminated limitations on damages and attorney's fee awards available through 
denying housing on the basis of disability; refusing to allow a handicapped person to make reasonable modifications to existing premises; ${ }^{96}$ and failing to design and construct multifamily dwellings in a manner accessible to the handicapped. ${ }^{97}$ In sweeping fashion, the FHAA requires that disabled people have access to the full array of housing opportunities.

The FHAA goes even further by stating that the purchaser or renter does not necessarily need to possess the disability at issue. Any disabled person who lives with, intends to live with, or is associated with a purchaser or renter also enjoys statutory protection. ${ }^{98}$ Furthermore, under $\S 3604(\mathrm{~b})$, the FHAA makes it unlawful for anyone to "discriminate against any person in the terms, conditions, or privileges of sale or rental of a dwelling, or in the provision of services or facilities in connection therewith" on the basis of a handicap. Thus, the FHAA protects both persons with handicaps as well as entities that provide the handicapped with housing. This includes group homes and nonprofit corporations that promote the interests of the disabled. ${ }^{99}$

litigation. See Fair Housing Amendments Act of 1988, secs. 7-8, $\$ \$ 808,810-812,102$ Stat. at 1623-33 (codified at 42 U.S.C. $\$ \S 3608,3610-3612$ ) (broadening HUD's ability to enforce FHAA provisions); id. sec. $6, \$ \S 804-806,102$ Stat. at 1622 (codified at 42 U.S.C. $\$ \S 3604-3606$ ) (expanding the scope of the FHAA to discrimination based upon familial status); id. sec. $8, \S 813,102$ Stat. at 1633-34 (codified at 42 U.S.C. $\$ 3613$ ) (providing that a court may award to the plaintiff actual and punitive damages without monetary limitation, injunctive relief, and reasonable attorney's fees).

${ }^{96}$ See $\$ 3604(f)(3)$ (stating that "discrimination includes . . . a refusal to permit, at the expense of the handicapped person, reasonable modifications of existing premises occupied or to be occupied by such person if such modifications may be necessary to afford such person full enjoyment of the premises").

${ }^{97}$ See $\$ 3604(f)(3)(C)$ ("Discrimination includes . . . in connection with the design and construction of covered multifamily dwellings for first occupancy . . . a failure to design and construct those dwellings in such a manner that ... the public use and common use portions of such dwellings are readily accessible to and usable by handicapped persons ....").

${ }^{98}$ See $\$ 3604(\mathrm{f})(1)(\mathrm{A})-(\mathrm{C})$ (" $[\mathrm{I}] \mathrm{t}$ shall be unlawful $[\mathrm{t}] \mathrm{o}$ discriminate . . . because of a handicap of $-(A)$ that buyer or renter; or $(B)$ a person residing in or intending to reside in that dwelling after it is so sold, rented, or made available; or $(C)$ any person associated with that buyer or renter.").

${ }^{99}$ It is well settled that a group home for recovering substance abusers has standing to bring FHAA claims individually and on behalf of its current and potential residents. See Oxford House-C v. City of St. Louis, 843 F. Supp. 1556, 1572 (E.D. Mo. 1994) (holding that Oxford House had individual standing to bring an FHAA claim because the zoning laws in dispute "perceptibly impaired" the organization by: (1) jeopardizing its ability to perform its state contract; (2) potentially causing the failure of the group home at issue; and (3) causing a substantial drain on Oxford House's resources, in its role as legal advocate for recovering addicts and alcoholics); Oxford 
Not only does the FHAA afford protection to many parties other than those with specific handicaps, but it also includes a definition of "handicap" that is itself extremely comprehensive. Both the Act and its accompanying administrative regulations are deliberately inclusive. ${ }^{100}$ Using section 504 of the Rehabilitation Act of $1973^{101}$ as its basis, ${ }^{102}$ the FHAA defines handicap as "(1) a physical or mental impairment which substantially limits one or more of such person's major life activities, (2) a record of having such impairment, or (3) being regarded as having such an impairment." 103 This definition encompasses anyone who has an actual disability, who is classified or labeled as having a disability, or who is treated by others as possessing a disability. ${ }^{104}$

House, Inc. v. City of Albany, 819 F. Supp. 1168, 1173-74 (N.D.N.Y. 1993) (finding that an Oxford House's function in founding and supervising program houses gives it sufficient interest in litigation as does the possibility of loss of state loans and funding if the housing is closed); $(f$. Havens Realty Corp. v. Coleman, 455 U.S. 363, 376 (1982) (holding that fair housing "testers" have standing to bring an FHAA claim "[a]s long as respondents have alleged distinct and palpable injuries that are 'fairly traceable' to petitioners' actions"); Growth Horizons, Inc. v. Delaware County, 983 F.2d 1277, 1281-82 (3d Cir. 1993) (holding that a corporation that provided residential placements for mentally retarded persons was "an aggrieved person" for purposes of the Fair Housing Act).

${ }^{100}$ See 42 U.S.C. \$ 3602(h); Preamble to Final Rule Implementing Fair Housing Amendments Act of 1988, 24 C.F.R. ch. 1, subch. A, app. 1 (1995) (rejecting recommendations that certain types of persons be specified in the definition of "handicapped" on the basis that such additions could be viewed as restrictive rather than as inclusive).

${ }^{101}$ Pub. L. No. 94-112, $§ 504,87$ Stat. 355, 395 (codified as amended at 29 U.S.C. $\S 794$ (1988)).

102 See H.R. REP. NO. 711, supra note 83, at 22 ("The Committee intends that the definition [of 'handicap'] be interpreted consistent with regulations clarifying the meaning of the similar provision found in Section 504 of the Rehabilitation Act."), reprinted in 1988 U.S.C.C.A.N. at 2183; see also 134 CoNG. REC. S10,492 (daily ed. Aug. 1, 1988) (statement of Sen. Simon) (stating that the Fair Housing Act's definition of handicap is the same as section 504 of the Rehabilitation Act of 1973, as amended); 134 CoNG. REC. H4689 (daily ed.June, 23 1988) (statement of Rep. Pelosi) ("This act represents a particularly important step forward because it extends the protection of the Fair Housing Act to people with disabilities. All people with disabilities . . . would be covered under the three-part definition of handicap adopted in this bill. This three-part definition of handicap is under section 504 of the Rehabilitation Act of 1973 .... Such coverage has been essential in section 504 and it is critical that the bill before us extends that same protection in private housing ...."). See generally Arlene S. Kanter, A Home of One's Own: The Fair Housing Amendments Act of 1988 and Housing Discrimination Against People with Mental Disabilities, 43 AM. U. L. REV. 925, 945-48 (1994) (comparing the FHAA's definition of "handicap" to the one found in $\$ 504$ of the Rehabilitation Act of 1973).

${ }^{103} 42$ U.S.C. $\$ 3602(\mathrm{~h})$. The statute does exclude from its definition current, illegal use of or addiction to a controlled substance. For a discussion of this limitation, see infra note 105 and accompanying text.

${ }^{104} C f$. GARY L. AlBrecht, The Disability Business: ReHabilitation IN AMERICA 
2. The FHAA Protects Recovering Substance Abusers

The FHAA protects former drug addicts and alcoholics from housing discrimination because these individuals are considered to be people with disabilities. The FHAA does not, however, cover current illegal drug users. ${ }^{105}$ Whereas those who live in group homes and who are in recovery enjoy fair housing protections, those who continue to abuse substances, regardless of where they live, do not.

The FHAA's definition of "handicap" is a functional one. It does not enumerate specific conditions to categorize and determine disabilities, but rather focuses on whether persons claiming housing discrimination on the basis of their handicaps endure physical or mental impairments that "substantially limit[] . . . major life activities." 106 Congress left the definition of "major life activities" to the Department of Housing and Urban Development (HUD), the agency responsible for administering the FHAA. ${ }^{107}$ HUD's parameters for interpreting the Act are extremely broad; caring for oneself, eating, walking, breathing, learning, working, seeing, hearing, and performing manual labor are all "major life activities." 108

The FHAA requires that any person with mental or physical restrictions that "substantially limit[] . . major life activities," any person who has a prior record of being so impaired, and even any person merely perceived or treated by others as having such limitations be defined as "handicapped." 109 This inclusive ap-

18-23 (1992) (commenting on the ambiguity that accompanies definitions of disability and discussing various interpretations).

${ }^{105}$ The relevant portion of the FHAA states: "Handicap' ... does not include current, illegal use of or addiction to a controlled substance." 42 U.S.C. $\S 3602(\mathrm{~h})$.

${ }^{106}$ See 42 U.S.C. \$ 3602(h); see also Patricia E. Salkin \& John M. Armentano, The Fair Housing Act, Zoning, and Affordable Housing, 25 URB. LAw. 893, 894 (1993) (explaining the FHAA definition of "handicap"); William Graham, Comment, There Goes the Neighborhood: The Evolution of "Family" in Local Zoning Ordinances, 9 TOURO L. REV. 699, 724-25 (1993) (discussing the scope of the "major life activities" clause); cf. Simring, supra note 83 , at $423-28$ (agreeing that the FHAA employs a functional approach in defining "major life activities" but questioning the vague boundaries the definition affords).

${ }^{107}$ See 42 U.S.C. $\$ 3608$.

${ }^{108}$ See 24 C.F.R. \$ 100.201 (1995).

${ }^{109}$ See 42 U.S.C. $\$ 3602(h)$; see also United States v. Southern Management Corp., 955 F.2d 914, 918-19 (4th Cir. 1992) (discussing the scope of the term "major life activities" and its application to former substance abusers); $c f .56 \mathrm{Fed}$. Reg. 35,544, 35,548-50 (1991) (implementing a similar operational definition of "disability" under the Americans with Disabilities Act). 
proach is compatible with congressional intent. The House Report that accompanied passage of the FHAA stated:

The Committee rejected the approach of excluding a category of individuals with disabilities from the protection of the Act. Instead, the Committee affirmed that all individuals with handicaps, with the exception of current illegal abusers or addicts of controlled substances, have access to the housing protections established by this Act. ${ }^{110}$

Congress included recovery from drug and alcohol addiction within the FHAA's definition of "handicap" for three reasons: (1) experts recognize substance abuse as a disease, and therefore, a disability:;11 (2) prior related legislation includes former addicts within the definition of disability; ${ }^{112}$ and (3) courts consider persons in recovery to be in need of protection from discrimination. ${ }^{113}$

${ }^{110}$ H.R. REP. NO. 711, supra note 83, at 28, reprinted in 1988 U.S.C.C.A.N. at 2189.

"II See id. at 22-23 (explaining that the American Psychiatric Association, the World Health Organization, and most other medical authorities identify addiction as a disease), reprinted in 1988 U.S.C.C.A.N. at 2183-84; see also AMERICAN PSYCHIATRIC ASS'N, DIAGNOSTIC AND STATISTICAL MANUAL OF MENTAL DISORDERS 194-204 (4th ed. 1994); 1 WORLD HEALTH ORG., MANUAL OF THE INTERNATIONAL STATISTICAL CLASSIFICATION OF DISEASES, INJURIES, AND CAUSES OF DEATH items 303-304 (1977). But cf. Frank H. Gawin \& Everett H. Ellinwood, Jr., Cocaine and Other Stimulants: Action, Abuse and Treatment, 318 NEW ENG.J. MED. 1173, 1176 (1986) (claiming that the withdrawal symptoms produced by drugs "fluctuate and are neither constant nor severe enough to meet psychiatric diagnostic criteria for major mood disorders").

112 See H.R. REP. No. 711, supra note 83, at 22 (comparing proposed FHAA provisions to $\S 504$ of the Rehabilitation Act of 1973, 29 U.S.C. $\$ 794$ (1988 \& Supp. V 1993)), reprinted in 1988 U.S.C.C.A.N. at 2183. The House Report suggests, in fact, that persons recovering from substance abuse and participating in treatment and selfhelp programs should be afforded full statutory protection from discrimination in precisely the same way as those who have disabilities that are more generally accepted. See id. at 29 ("The formulation of this amendment parallels the provision added to the Civil Rights Restoration Act of 1988 with regard to individuals with contagious diseases and infections ...." (footnote omitted)), reprinted in 1988 U.S.C.C.A.N. at 2190.

${ }^{113}$ See. e.g., Davis v. Bucher, 451 F. Supp. 791, 795-96 (E.D. Pa. 1978) (holding that prior addiction and drug use clearly fall within the definition of handicapped and noting that because "[d]rug addiction is a serious public problem, . . . [i]t is . . . not surprising that Congress would wish to provide assistance for those who have overcome their addiction and give some support and incentive for those who are attempting to overcome it"); id. at 797 (determining that one of the "clear purposes" of the Rehabilitation Act of 1973 "is to prevent employment discrimination against and expand employment opportunities for handicapped individuals"). See generally Anne Robbins, Note, Employment Discrimination Against Substance Abusers: The Federal Response, 33 B.C. L. REV. 155, 169-90 (1991) (discussing judicial interpretation of $\S 504$ of the Rehabilitation Act of 1973 as applied to substance abuse). 
Numerous judicial opinions have recognized Congress's intent to afford recovering substance abusers protection from housing discrimination, while excluding current addicts from similar coverage. ${ }^{114}$ The leading authority on recovering substance abusers' rights under the FHAA is the 1992 decision, United States v. Southern Management Corp. ${ }^{115}$ in which the Fourth Circuit held that a management company's refusal to rent apartments to a program dedicated to recovering drug addicts and alcohol abusers violated the FHAA. ${ }^{116}$ The court recognized Congress's explicit focus on rehabilitation, its specific reference to drug addiction, and its distinction between current and former users. The court concluded that addicts are covered by the FHAA as long as they can demonstrate that (1) they are perceived as having an impairment and (2) they are not currently using illegal substances. ${ }^{117}$ Later cases have almost consistently followed suit. ${ }^{118}$ Oxford House, Inc.

${ }^{114}$ See, e.g., United States v. Southern Management Corp., 955 F.2d 914, 922-23 (4th Cir. 1992) (rejecting the defendant's argument that because one never ceases to be an "addict" under the medical definition, all current and former drug users are excluded from the protections of the FHAA); United States v. Borough of Audubon, 797 F. Supp. 353, 358 (D.N.J. 1991) (citing $\$ 504$ of the Rehabilitation Act of 1973 and the House Report as bases for finding Oxford House residents handicapped within the meaning of the FHAA), affd, 968 F.2d 14 (3d Cir. 1992).

115955 F.2d 914 (4th Cir. 1992).

${ }^{116} \mathrm{See}$ id. at 923 ("Our ruling is fair notice regarding the ambit of the Act's coverage of drug addicts/abusers. The Rehabilitation Act's current definition ... should serve as a definitive guidepost for all future controversies under the Fair Housing Act."). But see Oxford House, Inc. v. Township of Cherry Hill, 799 F. Supp. $450,459-60$ \& $n .21$ (D.N.J. 1992) (including recovering substance abusers in the definition of "handicap" but labeling the Fourth Circuit's approach a "bootstrap argument"); $c f$. Robert L. Schonfeld \& Seth P. Stein, Fighting Municipal "Tag-Team": The Federal Fair Housing Amendments Act and Its Use in Obtaining Access to Housing for Persons with Disabilities, 21 FORDHAM URB. L.J. 299, 304-05 (1994) (analyzing methods for defining handicap under the FHAA).

${ }^{117}$ See Southern Management Corp., 955 F.2d at 922 ("The explicit focus on successful rehabilitation and supervised programs assures us that Congress accepts the concept of the rehabilitated addict.").

${ }^{118}$ See, e.g., City of Edmonds v. Washington State Bldg. Code Council, 18 F.3d 802, 804 (9th Cir. 1994) ("Participation in a supervised drug rehabilitation program, coupled with non-use, meets the definition of handicapped."), aff'd sub nom. City of Edmonds v. Oxford House, Inc., 115 S. Ct. 1776 (1995); cf. Stewart B. McKinney Found., Inc. v. Town Plan \& Zoning Comm'n, 790 F. Supp. 1197, 1211-16 (D. Conn. 1992) (concluding that individuals with AIDS or HIV are protected under the FHAA).

Although the courts have been unwilling to broaden the current illegal substance abuser exemption in cases involving the FHAA, a small number of recent decisions in other disability law contexts interpret "current" as including the recent past. See Teahan v. Metro-North Commuter R.R., 951 F.2d 511, 520 (2d Cir. 1991) (stating that under $\$ 504$ of the Rehabilitation Act, "'[c]urrent' is to be determined in light of . . . whether the employee's substance abuse problem is severe and recent enough so that 
v. Township of Cherry Hill ${ }^{119}$ provides a thorough judicial analysis of FHAA coverage of alcoholism and drug addiction. Although its analytical framework is slightly different from that of Southern Management Corp., the court cites extensive expert testimony on the "severe limitations" a history of addiction places on individuals. ${ }^{120}$

\section{B. Proving an FHAA Violation}

The FHAA provides a comprehensive arsenal of weapons to combat bias against people with disabilities. Although the statute does not explicitly state the ways to establish a housing discrimination claim, courts have employed three separate methods: proving discriminatory intent, ${ }^{121}$ proving discriminatory effect, ${ }^{122}$ and showing a failure to provide reasonable accommodations. ${ }^{123}$ The existence of such extensive methods of proof bolster the notion that sweeping measures are needed to protect effectively the civil rights of people with disabilities.

the employer is justified in believing that the employee is unable to perform the essential duties of his job"); cert. denied, $113 \mathrm{~S}$. Ct. 54 (1992); see also McDaniel v. Mississippi Baptist Medical Ctr., 877 F. Supp. 321, 327-28 (S.D. Miss. 1995) (holding that a person is protected by the Americans with Disabilities Act only if he has been in recovery long enough to become stable).

119799 F. Supp. 450 (D.N.J. 1992).

${ }^{120}$ See id. at 460 (discussing the obstacles of drug and alcohol rehabilitation and explaining the "crucial importance" of the "supportive and drug-free environment" provided by residences serving former addicts' needs).

${ }^{121}$ See, e.g., United States v. Borough of Audubon, 797 F. Supp. 353, 360-61 (D.N.J. 1991) (holding that a municipality violated the FHAA by taking actions and making statements to prevent the siting of a group home for recovering substance abusers), affd, $968 \mathrm{~F} .2 \mathrm{~d} 14$ (3d Cir. 1992); see also infra notes 124-27 and accompanying text (describing discriminatory intent under the FHAA).

${ }_{122}$ See, e.g., NAACP v. Town of Huntington, 844 F.2d 926, 941-42 (2d Cir.) (invalidating a zoning ordinance limiting construction of multifamily dwellings because it had the effect of discriminating against racial minorities), affd, 488 U.S. 15 (1988) (per curiam); United States v. City of Black Jack, 508 F.2d 1179, 1188 (8th Cir. 1974) (striking down an ordinance because of its racially discriminatory effect), cert. denied, 422 U.S. 1042 (1975); see also infra notes $128-42$ and accompanying text (discussing the discriminatory effect test).

${ }^{123}$ See, e.g., City of Edmonds v. Washington State Bldg. Code Council, 18 F.3d 802, 806 (9th Cir. 1994) (holding that a zoning ordinance was not exempt from FHAA prohibitions because exemption would undermine the FHAA's intended purpose of accommodating the handicapped), affd sub nom. City of Edmonds v. Oxford House, Inc., $115 \mathrm{~S}$. Ct. 1776 (1995). The court based its conclusion on the "reasonable accommodations" provision of the FHAA. See 42 U.S.C. $\$ 3604(f)(3)(B)$ (stating that "discrimination includes ... . a refusal to make reasonable accommodations in rules, policies, practices, or services, when such accommodations may be necessary to afford such person equal opportunity to use and enjoy a dwelling"). 
The clearest FHAA violations involve intentional discrimination. Under $\$ 3604(f)(1)$, it is unlawful "[t]o discriminate in the sale or rental, or to otherwise make unavailable or deny" a person the housing of his or her choice because of a handicap. ${ }^{124}$ To determine whether intentional discrimination has occurred, courts generally examine how the disputed actions have affected the complaining party and the particular circumstances leading to the claim. ${ }^{125}$ For group homes for recovering substance abusers, statements of municipal officials and actions by local zoning boards have sometimes, although not always, been sufficient to prove an FHAA violation. ${ }^{126}$ When, for instance, a town's mayor and police department attend a town meeting in order to develop a strategy for harassing and discouraging those seeking to establish a group home, a court is likely to find an FHAA violation. ${ }^{127}$

A second way to prove an FHAA violation is by showing a discriminatory effect. ${ }^{128}$ Under the discriminatory effects test, a

12442 U.S.C. § $3604(f)(1)$.

${ }^{125}$ See Stewart B. McKinney Found., Inc. v. Town Plan \& Zoning Comm'n, 790 F. Supp. 1197, 1219-20 (D. Conn. 1992) (invalidating a municipal special permit requirement motivated, in part, by the HIV status of persons who were to live on the property); Support Ministries for Persons with AIDS v. Village of Waterford, 808 F. Supp. 120, 133-35 (N.D.N.Y. 1992) (inferring intentional discrimination from the chain of events surrounding one organization's attempt to provide housing for homeless persons with AIDS); see also Salkin \& Armentano, supra note 106, at 897-88 (discussing McKinney and Support Ministries); Schonfeld \& Stein, supra note 116, at 315-18 (explaining judicial application of the FHAA).

${ }^{126}$ See, e.g., Oxford House-C v. City of St. Louis, 843 F. Supp. 1556, 1575-76 (E.D. Mo. 1994) (finding that officials' opposition to the site of a group home for recovering substance abusers was based upon stereotypical fears and therefore constituted intentional discrimination). But cf. Smith \& Lee Assocs. v. City of Taylor, 13 F.3d 920, 927-28 (6th Cir. 1993) (overruling a district court finding of discriminatory intent based upon the action of city council members and historical background).

${ }^{127}$ See United States v. Borough of Audubon, 797 F. Supp. 353, 360 (D.N.J. 1991) (concluding that the actions and statements of local officials provided considerable evidence of discriminatory animus), affd, 968 F.2d 14 (3d Cir. 1992). But see Smith $\mathcal{E}$ 'Lee Assocs., $13 \mathrm{~F} .3 \mathrm{~d}$ at 933 (finding that an official's actions and a city's refusal to rezone did not constitute intentional discrimination).

One recent decision indicates that an FHAA violation will not be found, however, if local residents similarly conspire without the aid of local officials. See Michigan Protection and Advocacy Serv. v. Babin, 18 F.3d 337, 345-46 (6th Cir. 1994) (holding that the actions of the neighbors of a proposed group home did not constitute an FHAA violation even with the presence of a discriminatory motive).

${ }^{128}$ See, e.g., Oxford House-C, 843 F. Supp. at 1575 (acknowledging that an FHAA violation can be proven by showing either intentional discrimination or discriminatory effect); Potomac Group Home Corp. v. Montgomery County, 823 F. Supp. 1285, 1294 (D. Md. 1993) (" [A] plaintiff may prevail under the FHAA by showing 'discriminatory intent,' or by showing a 'discriminatory impact.'"). 
plaintiff can establish a prima facie case of discrimination by proving that a given practice has a more detrimental impact on the housing rights of persons with disabilities than it has on the rights of persons without similar handicaps. ${ }^{129}$ Under this test, proof of discriminatory intent is unnecessary. ${ }^{130}$ Thus, in the context of group homes for recovering substance abusers, even when they cannot prove that city, town, or zoning board exclusion is motivated by aversion toward them in particular, former addicts and alcoholics may nonetheless be afforded FHAA protection.

Both the legislative history of the bill's passage and the bulk of court analysis solidly supports use of the discriminatory effects test, even though the FHAA is silent on its face about this method of proof. The House Committee Report accompanying passage of the FHAA states:

The Committee understands that housing discrimination against handicapped persons is not limited to blatant, intentional acts of discrimination. Acts that have the effect of causing discrimination can be just as devastating as intentional discrimination. A person using a wheelchair is just as effectively excluded from the opportunity to live in a particular dwelling by a lack of access into a unit and by too narrow doorways as by a posted sign saying "No Handicapped People Allowed."

According to the same logic, communities do not need zoning laws that explicitly state "No Group Homes for Recovering Addicts Allowed" in order to violate the FHAA; ordinances and procedures that have a discriminatory impact on such programs are equally illegal. To support use of the effects test, the House Committee Report compares enforcement of FHAA claims with discrimination suits brought under section 504 of the Rehabilitation Act of 1973. The report cites Alexander $v$. Choate, ${ }^{132}$ the seminal case endorsing

${ }^{129}$ See, e.g., Doe v. City of Butler, 892 F.2d 315, 323 (3d Cir. 1989) ("To make out a prima facie case under Title VIII (the Fair Housing Act), a plaintiff can show either discriminatory treatment, or discriminatory effect alone, without proof of discriminatory intent." (citations omitted)).

${ }^{130}$ Cf. Griggs v. Duke Power Co., 401 U.S. 424, 431 (1971) (holding that Title VII of the Civil Rights Act of 1964 prohibited an employer from requiring as a condition of employment that employees possess a high school education or a passing grade on a standardized general intelligence test, neither of which bore a demonstrable relationship to successful job performance, because the Act "proscribes not only overt discrimination but also practices that are fair in form, but discriminatory in operation").

${ }^{191}$ H.R. REP. No. 711, supra note 83, at 25, reprinted in 1988 U.S.C.C.A.N. at 2186.

132469 U.S. 287 (1985). 
the use of the discriminatory impact test to prove discrimination against disabled persons under section 504, stating, "The Supreme Court observed that discrimination on the basis of handicap is 'most often the product, not of invidious animus, but rather of thoughtlessness and indifference-of benign neglect.'n133

Furthermore, although the Supreme Court has not directly addressed the issue whether discriminatory intent is necessary to establish an FHAA violation, nearly all federal courts of appeals have determined that a showing of a discriminatory effect, even in the absence of discriminatory intent, is sufficient to establish a violation. ${ }^{134}$ Indeed, courts apply the discriminatory effects test to fair housing cases in much the same way as they do to cases involving section 504 of the Rehabilitation Act of $1973 .{ }^{135}$ Although the method of proof is essentially the same in most circuits, different appeals courts employ slightly different tests for

${ }^{13 s}$ H.R. REP. No. 711, supra note 83, at 25 (quoting Alexander v. Choate, 469 U.S. at 295), reprinted in 1988 U.S.C.C.A.N. at 2186. In Alexander v. Choate, Tennessee Medicaid recipients claimed that the state violated $\S 504$ of the Rehabilitation Act of 1973 when it reduced the annual number of inpatient hospital days Medicaid would cover. See 469 U.S. at 289 . Although the recipients lost this particular battle, see id. at 309, the Supreme Court did suggest that proof of discriminatory impact is sufficient to establish unlawful discrimination. Justice Marshall, writing for the majority, commented that "much of the conduct that Congress sought to alter in passing the Rehabilitation Act would be difficult if not impossible to reach were the Act construed to proscribe only conduct fueled by a discriminatory intent." Id. at 296-97.

${ }^{134}$ See, e.g., United States v. City of Black Jack, 508 F.2d 1179, 1184 (8th Cir. 1974) (employing the discriminatory impact test in a case involving racial discrimination), cert. denied, 422 U.S. 1042 (1975). The court in City of Black Jack explained:

To establish a prima facie case of racial discrimination, the plaintiff need prove no more than that the conduct of the defendant actually or predictably results in ... discrimination; in other words, that it has a discriminatory effect. The plaintiff need make no showing whatsoever that the action resulting in racial discrimination in housing was racially motivated.

See id. at 1184-85 (citations and footnote omitted); see also Huntington Branch, NAACP v. Town of Huntington, 844 F.2d 926, 934 (2d Cir. 1988) (determining that the disparate impact approach utilized in Title VII cases is fully applicable to Title VIII claims); Metropolitan Hous. Dev. Corp. v. Village of Arlington Heights, 558 F.2d 1283, 1289-90 (7th Cir. 1977) (determining that although discriminatory intent was necessary to prove a constitutional violation, such proof was not required for establishing a prima facie FHA claim).

For a comprehensive discussion of the FHAA and the discriminatory impact test, see generally Kanter, supra note 102, at 979-82.

${ }^{195}$ See, e.g., Elliott v. City of Athens, 960 F.2d 975, $981-84$ (11th Cir.) (citing Alexander v. Choate, 469 U.S. 287 (1985)), cert. denied, 113 S. Ct. 376 (1992); see also Oxford House-C v. City of St. Louis, 843 F. Supp. 1556, 1577-80 (E.D. Mo. 1994) (discussing judicial precedent when applying the discriminatory impact test to a case involving a group home for recovering substance abusers). 
proving discriminatory impact. The Seventh Circuit, for example, assesses four factors in discriminatory impact cases: (1) the strength of the plaintiff's proof of discriminatory effect; (2) whether there is some, although not necessarily sufficient, evidence of discriminatory intent; (3) the defendant's interest in taking the allegedly discriminatory action; and (4) whether the plaintiff seeks to compel the defendant to provide housing or whether the plaintiff merely wishes that the defendant refrain from interfering with individual property owners who want to provide such housing. ${ }^{136}$ The Eighth Circuit, in United States $v$. City of Black Jack, ${ }^{137}$ established a slightly different test. A plaintiff must first establish a prima facie case of discriminatory effect. Once established, the burden shifts to the defendant to demonstrate that such conduct is necessary to promote a sufficiently compelling interest. ${ }^{138}$ Indeed, the Eighth Circuit reaffirmed the import of the effects test in this case, commenting, "[e]ffect, and not motivation, is the touchstone" of a Fair Housing Act claim "because clever men may easily conceal their motivations, but more importantly, because .. . 'the arbitrary quality of thoughtlessness can be as disastrous and unfair to private rights and the public interest as the perversity of a willful scheme." 139

Although the effects test is generally accepted, not all courts apply it willingly 140 and not all politicians favor its stringent enforcement. ${ }^{141}$ Attorney General Janet Reno, however,

${ }^{196}$ See Village of Arlington Heights, 558 F.2d at 1290.

137508 F.2d 1179 (8th Cir. 1974), cert. denied, 422 U.S. 1042 (1975).

${ }^{138}$ See id. at 1184-85; see also Oxford House-C, 843 F. Supp. at 1577 (employing the City of Black Jack court's test for proving discriminatory impact).

${ }^{139}$ City of Black Jack, 508 F.2d at 1185 (quoting Hobson v. Hansen, 269 F. Supp. 401,497 (D.D.C. 1967), affd sub nom. Smuck v. Hobson, 408 F.2d 175 (1969) (en banc)).

${ }^{140}$ See Familystyle of St. Paul, Inc. v. City of St. Paul, 923 F.2d 91, 94-95 (8th Cir. 1991) (holding that state and municipal dispersal requirements specifically addressing group homes did not violate the FHAA). In Familystyle, the Eighth Circuit ignored the discriminatory impact test that it had previously announced in City of Black Jack and instead employed a rational relationship test as articulated in City of Cleburne v. Cleburne Living Center, Inc., 473 U.S. 432, 446 (1985), the appropriate standard prior to enactment of the FHAA, when people with disabilities were not considered a suspect class. See Familysiyle, 923 F.2d at 94 . Using the wrong test to assess the discriminatory impact of this dispersal requirement, the court found that the state aim of promoting deinstitutionalization justified this otherwise discriminatory action. See id. at $94-95$.

${ }^{141}$ See W. John Moore, On the March Again?, 24 NAT'L J. 2824, 2828 (1992) (commenting that although the Bush Administration attacked some types of housing discrimination, during its tenure, the Departments of Justice and HUD refused to bring discriminatory-effects lawsuits). In fact, when signing the FHAA, President 
champions application of the discriminatory effect test in housing discrimination cases, encouraging the Department of Justice to challenge incidents of "subtle ... not even conscious . . . discrimination" taking the form of "bad service, indifference, ... [and] thoughtlessness." 142

Discriminatory intent and discriminatory effect are the two traditional methods of finding an FHAA violation. Indeed, courts and commentators often interpret this legislation to mean that these are the only methods of proving unlawful housing discrimination. ${ }^{143}$

Reagan was far less enthusiastic than Congress and the courts about establishing FHAA claims by proving discriminatory impact. He stated:

At the same time, I want to emphasize that this bill does not represent any congressional or executive branch endorsement of the notion, expressed in some judicial opinions that title 8 violations may be established by a showing of disparate impact or discriminatory effects of a practice that is taken without discriminatory intent. Title 8 speaks only to intentional discrimination.

Remarks on Signing the Fair Housing Amendments Act of 1988, supra note 77, at 1156.

This comment, which directly contradicted legislative history, was met by Senator Edward Kennedy with a pointed response:

Unfortunately, President Reagan used that historic occasion to announce an interpretation of the act that this [sic] flatly inconsistent with Congress's understanding of the law. The President suggested that the act should be read as requiring proof of discriminatory intent in order to establish a violation of the fair housing law.

$\cdots$

As the principal Senate sponsor of the $1988 \mathrm{act}$, I can state unequivocally that Congress contemplated no such intent requirement. The act did not materially alter the 1968 Fair Housing Act provisions defining what is required to prove a discriminatory housing practice. All of the Federal courts of appeals that have considered the question have concluded that title VIII should be construed, at least in some instances, to prohibit acts that have discriminatory effects, and that there is no need to prove discriminatory intent.

134 CoNG. REc. $S 12,449$ (daily ed. Sept. 14, 1988).

${ }^{142}$ Reno Approves 'Disparate Impact' for Housing Cases, DEP'T JUST. ALERT, Feb. 7, 1994, at 5; cf. Policy Statement on Discrimination in Lending, 59 Fed. Reg. 18,266, 18,268-70 (1994) (stating that to effectuate the FHAA, as well as the Equal Credit Opportunity Act, evidence of disparate impact, absent a justified business necessity, is evidence of discrimination).

${ }^{143}$ See, e.g., Association of Relatives and Friends of AIDS Patients v. Regulations and Permits Admin., 740 F. Supp. 95, 103 (D.P.R. 1990) ("There are two methods of showing discrimination in violation of section 3604 . The first method requires a showing of 'discriminatory intent.' ... The second method, known as 'disparate impact' analysis, examines whether the effect of a defendant's action is unnecessarily discriminatory even though no intent to discriminate is shown."); Salkin \& Armentano, supra note 106, at 894 ("To prove discrimination under the FHA, plaintiffs must demonstrate either intentional discrimination, discriminatory impact, or disparate treatment."). 
There is, however, a third alternative: the FHAA's "reasonable accommodations" clause.

The FHAA clearly establishes that, in addition to the more traditional techniques of demonstrating civil rights violations, a disabled person's housing rights are violated when one party fails to "make reasonable accommodations in rules, policies, practices, or services, when such accommodations may be necessary to afford such person equal opportunity to use and enjoy a dwelling." 144 This has been defined as "changing some rule that is generally applicable so as to make its burden less onerous on the handicapped individual." 145 Yet, in spite of $\S 3604$ of the FHAA, ${ }^{146}$ which provides an explicit statutory basis for this claim, the courts frequently rely only on the intent and effects tests and ignore the provision allowing claimants to bring an action for failure to provide reasonable accommodations. ${ }^{147}$ A number of recent judicial decisions incorrectly equate a failure to provide reasonable accommodations with a policy that has a discriminatory effect. In these cases, the "reasonable accommodations" provision acts merely as an element of another method of proof-the effects test-rather than as an independent means to establish unlawful housing discrimination. ${ }^{148}$

Some jurisdictions nonetheless accept the independent "reasonable accommodations" standard. In a recent case involving a city's refusal to modify a side-yard zoning requirement, for example, one

14442 U.S.C. $\$ 3604(\mathrm{f})(3)(\mathrm{B})$; see also infra part IV.A (providing a thorough evaluation of the "reasonable accommodations" clause and recommending how it should be interpreted).

${ }^{145}$ North Shore-Chicago Rehabilitation Inc. v. Village of Skokie, 827 F. Supp. 497, 499 (N.D. Ill. 1993) (quoting Oxford House, Inc. v. Township of Cherry Hill, 799 F. Supp. 450, 462 n.25 (D.N.J. 1992)); see also United States v. City of Phila., 838 F. Supp. 223, 228 (E.D. Pa. 1993) (stating that the "reasonable accommodations" clause requires cities to "change, waive, or make exceptions in their zoning rules to afford people with disabilities the same opportunity to housing as those who are without disabilities" (quoting Horizon House Developmental Servs., Inc. v. Township of Upper Southampton, 804 F. Supp. 683, 699-700 (E.D. Pa. 1992))).

${ }^{146}$ See $\$ 3604(f)(3)(B)$.

${ }^{147}$ See infra part III.B.

${ }^{148}$ See, e.g., City of St. Joseph v. Preferred Family Healthcare, Inc., 859 S.W.2d 723, 727 (Mo. Ct. App. 1993) (holding that an aggrieved party must prove that the city "sought to discriminate" in order to establish an FHAA violation). But see Oxford House-C v. City of St. Louis, 843 F. Supp. 1556, 1581 (E.D. Mo. 1994) ("Failure to make reasonable accommodations is an independent Fair Housing Act violation .... ); Oxford House, Inc. v. City of Va. Beach, 825 F. Supp. 1251, 1257 (E.D. Va. 1993) (" $[A]$ plaintiff can establish a violation of the Fair Housing Act by demonstrating either intentional discrimination or discriminatory impact, or a refusal to make reasonable accommodations for the handicapped." (citation omitted)). 
district court clearly embraced this separate method of establishing discrimination. ${ }^{149}$ Furthermore, the only Supreme Court decision involving FHAA coverage of group homes for recovering substance abusers was evaluated explicitly under the "reasonable accommodations" provision. ${ }^{150}$ Yet, as will be discussed in Part III, the success of bringing a claim under $\$ 3604$, the "reasonable accommodations" provision, has been limited at best. It remains the least recognized, most misconstrued way to protect and enforce the housing rights of disabled persons. ${ }^{151}$

\section{Exceptions to the FHAA}

There are only a few exceptions to the broad protection afforded under the FHAA. With regard to group homes for recovering substance abusers, only three are particularly relevant. First, current users of drugs and alcohol are expressly excluded from the FHAA's protection. ${ }^{152}$ Second, those who pose a direct threat to the health or safety of others are also exempted..$^{153}$ Third, and finally, the FHAA does not affect "reasonable local, State, or Federal restrictions regarding the maximum number of occupants permitted to occupy a dwelling." 154 Although these limits on the applicability of the FHAA initially may appear to be far-reaching, they actually provide municipalities with little ammunition to circumvent their obligations under the FHAA and combat the establishment of group homes in their communities. Congress intended that these provisions be narrowly construed and applied only in specific, limited circumstances. ${ }^{155}$

149 See Cily of Phila., 838 F. Supp. at 230 ("To read § 3604(f)(3) as requiring a showing of disparate impact-that is, a showing sufficient to establish liability under $\S \S 3604(f)(1) \&(2)-w o u l d$ render $\$ 3604(f)(3)$ superfluous."), affd, $30 \mathrm{~F} .3 \mathrm{~d} 1488$ (3d Cir. 1994).

${ }^{150}$ See City of Edmonds v. Oxford House, Inc., 115 S. Ct. 1776, 1779 (1995) ("Discrimination covered by the FHAA includes a refusal to make reasonable accommodations .....").

${ }^{151}$ See infra part IV.A (providing a detailed analysis of the "reasonable accommodations" standard).

${ }^{152}$ See 42 U.S.C. \$ 3602(h) ("Handicap' . . . does not include current, illegal use of or addiction to a controlled substance . . . ."); supra part II.A.2 (discussing judicial interpretation of the FHAA's "current users" provision).

${ }^{153}$ See 42 U.S.C. $\$ 3604(f)(9)$ ("Nothing in this subsection requires that a dwelling be made available to an individual whose tenancy would constitute a direct threat to the health or safety of other individuals or whose tenancy would result in substantial physical damage to the property of others.").

15442 U.S.C. $\$ 3607(b)(1)$.

${ }^{155}$ See Hogar Agua y Vida en el Desierto, Inc., v. Suarez-Medina, 36 F.3d 177, 181 
For group homes for recovering substance abusers, the "direct threat" and "current users" provisions, in tandem, are the most important FHAA exemptions. They help to ensure that former users in recovery are able to get the housing support they need while denying current drug and alcohol abusers similar protections. As previously discussed, although current drug and alcohol users are not afforded FHAA protections, former addicts are. ${ }^{156}$ In accord with this distinction between those who are in recovery and those who are not, both Congress and the courts have interpreted the "direct threat" provision in a manner that prevents cities and towns from using this exemption as a back-door method to exclude group homes for recovering substance abusers.

The "direct threat" exclusion provides:

Nothing in this subsection requires that a dwelling be made available to an individual whose tenancy would constitute a direct threat to the health or safety of other individuals or whose tenancy would result in substantial physical damage to the property of others. ${ }^{157}$

The House Committee Report clearly indicates that it is inappropriate to uniformly exclude specific classes of otherwise eligible handicapped persons. ${ }^{158}$ Indeed, the House Committee Report states that all direct threat claims must be based upon a "history of overt acts or current conduct" rather than on inferences based on recent history or a disability. ${ }^{159}$

(1st Cir. 1994) (denying an owner's claim to an exemption to the FHAA in a suit involving a group home for persons infected with HIV, and stating that "the presumption that ambiguous language in a remedial statute is entitled to a generous construction consistent with its reformative mission" has been "relied on consistently by the courts in interpreting the omnibus remedial provisions of the Civil Rights Act of 1968, which prominently include the Fair Housing Act itself"); see also infra notes 161-70 and accompanying text (describing how the Supreme Court has agreed with this interpretation).

${ }^{156}$ See supra notes 117-20 and accompanying text (discussing judicial interpretation of the FHAA's "current users" provision).

${ }^{157} 42$ U.S.C. $\$ 3604(f)(9)$.

${ }^{158}$ See H.R. REP. NO. 711, supra note 83 , at 28 ("[T] he Committee affirmed that all individuals with handicaps, with the exception of current illegal abusers or addicts of controlled substances, have access to the housing protections established by this Act."), reprinted in 1988 U.S.C.C.A.N. at 2189. Indeed, the same report specifically stated that " $[\mathrm{g}]$ eneralized assumption, subjective fears, and speculation are insufficient to prove the requisite direct threat to others." Id. at 29, reprinted in 1988 U.S.C.C.A.N. at 2190.

${ }^{159}$ See id. at 29-30, reprinted in 1988 U.S.C.C.A.N. at 2190-91. 
Courts have agreed with Congress's inclination to restrict application of the "direct threat" provision. In United States $v$. Southern Management Corp., the Fourth Circuit held that "[j]ust like any other person with a disability, such as cancer or tuberculosis, former drug-dependent persons do not pose a threat to a dwelling or its inhabitants simply on the basis of status. ${ }^{\text {160 }}$ This interpretation, in tandem with the limited application afforded the exclusion for current substance abusers, indicates an unequivocal legislative policy to afford broad housing rights to group homes for recovering substance abusers.

If City of Edmonds $v$. Oxford House, Inc. ${ }^{161}$ is an accurate indicator of the Supreme Court's overall outlook toward the FHAA, it seems unlikely that this scheme of broad coverage and narrow exceptions will be easily frustrated. In this six-to-three decision, the Court held that a Seattle suburb could not exempt a zoning ordinance from FHAA coverage merely by labeling it a "maximum occupancy limitation." 162 Although $\S 3607(\mathrm{~b})(1)$ does provide that "[n]othing in [the FHAA] limits the applicability of any reasonable local, State, or Federal restrictions regarding the maximum number of occupants permitted to occupy a dwelling, ${ }^{n 163}$ the Court held that this exemption did not apply to Edmonds's ordinance. Landuse restrictions that typically delineate compatible and incompatible uses of property in categories such as single-family residential,

${ }^{160} 955$ F.2d 914, 921 (4th Cir. 1992); see also Association of Relatives and Friends of AIDS Patients v. Regulations and Permits Admin., 740 F. Supp. 95, 103 (D.P.R. 1990) (finding no evidence to support the conclusion that a group home for 10 terminally ill AIDS patients constituted a "direct threat" under \$ 3604(f)(9)); Baxter v. City of Belleville, 720 F. Supp. 720, 735 (S.D. Ill. 1989) (holding that "[i]rrational hysteria and public panic cannot support activity that violates the FHA[A] and is clearly discriminatory"); cf. School Bd. v. Arline, 480 U.S. 273, 285-86 (1987) (requiring that the decision to exclude a teacher with tuberculosis from the classroom must be based on an individualized inquiry regarding the health and safety risk she poses to others).

161115 S. Ct. 1776 (1995).

${ }^{162}$ See id. at 1779 .

The defining provision at issue describes who may compose a family unit; it does not prescribe "the maximum number of occupants" a dwelling unit may house. We hold that $\S 3607(b)(1)$ does not exempt prescriptions of the family-defining kind, i.e:; provisions designed to foster the family character of a neighborhood. Instead, $\$ 3607(b)(1)$ 's absolute exemption removes from the FHA's scope only total occupancy limits, i.e., numerical ceilings that serve to prevent overcrowding in living quarters.

Id.

${ }^{169} 42$ U.S.C. $\$ 3607(b)(1)$. 
multiple-family residential, commercial, or industrial, ${ }^{164}$ the Court explained, should be distinguished from maximum-occupancy restrictions, which traditionally are based upon available floor and room space and are devised to protect health and safety by preventing overcrowding. ${ }^{165}$ The exception to the FHAA described in $\S$ $3607(\mathrm{~b})(1)$ applies only to the latter category. ${ }^{166}$ Edmonds's zoning rule, which defined "family" in a manner that limited the maximum number of unrelated persons who could live in a single-family residential neighborhood but which did not similarly restrict the maximum number of related persons who could cohabitate, ${ }^{167}$ constituted a land-use rule, rather than an occupancy limit, and therefore was not exempt. The Court remanded the case to the district court to determine the question whether the city of Edmonds's actions against Oxford House violated the FHAA. ${ }^{168}$

Much of the Court's opinion in Edmonds was premised upon an expansive reading of the FHAA. To support the distinction between land-use regulations and maximum-occupancy restrictions, Justice Ginsburg discussed legislative intent at length and relied upon principles of statutory construction that fostered liberal application of the FHAA. She noted the FHAA's "broad and inclusive' compass" and therefore accorded its enforcement provisions "generous construction," 169 regarding the "case as an instance in

${ }^{164}$ See $115 \mathrm{~S}$. Ct. at 1780 (describing typical zoning restrictions).

165 See id. at 1781 (stating that land-use restrictions aim to secure "zones where family values, youth values, and the blessings of quiet seclusion and clean air make the area a sanctuary for people" and involve the definition of the term "family," whereas maximum-occupancy restrictions "ordinarily apply uniformly to all residents of all dwelling units" and have as their purpose the prevention of overcrowding within a dwelling (quoting Village of Belle Terre v. Boraas, 416 U.S. 1, 9 (1974))); see also id. at 1782 ("[R]ules that cap the total number of occupants in order to prevent overcrowding of a dwelling 'plainly and unmistakably' fall within $\$ 3607(\mathrm{~b})(1)$ 's absolute exemption from the FHA's governance; rules designed to preserve the family character of a neighborhood, fastening on the composition of households rather than on the total number of occupants living quarters can contain, do not." (citation omitted) (emphasis added)).

${ }^{166}$ See id. at $1781-82$ (stating that although $\S 3607(\mathrm{~b})(1)$ "surely encompasses maximum occupancy restrictions," its language "does not fit family composition rules typically tied to land use restrictions"); id. at 1780 ("Congress enacted $\$ 3607(\mathrm{~b})(1)$ against the backdrop of an evident distinction between municipal land use restrictions and maximum occupancy restrictions.").

${ }^{167}$ See id. at 1778-79 (citing Edmonds Community Development Code $§ 21.30 .010$ (1991), which provides that occupants of single-family dwelling units must compose a "family" and defining family as "persons [without regard to number] related by genetics, adoption, or marriage, or a group of five or fewer [unrelated] persons" (alteration in original)).

${ }^{168}$ See id. at 1783.

${ }^{169}$ Id. at 1780 (quoting Trafficante v. Metropolitan Life Ins. Co., 409 U.S. 205, 
which an exception to 'a general statement of policy' is sensibly read 'narrowly in order to preserve the primary operation of the [policy]."170 Although the Edmonds court construed only one narrow provision of the FHAA, and although the Court did not directly invalidate the discriminatory regulation at issue, the import of the Edmonds decision should not be underestimated. Edmonds affirms the FHAA's role in protecting from discrimination group homes for recovering substance abusers and limits local power to circumvent this important statute.

\section{The USE OF THE ZONING Process to EXCLUDE GROUP HOMES FOR RECOVERING SUBSTANCE ABUSERS}

\section{A. Local Resistance to Group Homes for Recovering Substance Abusers}

For every group home that is successfully established, experts estimate that another closes or never opens because of community opposition. ${ }^{171}$ Community living programs, including those serving individuals with mental or developmental disabilities, AIDS sufferers, and the homeless, often meet the cry, "Not in my backyard. ${ }^{172}$ The opposition is everywhere-in the press ${ }^{173}$ and

209, 212 (1972)).

${ }^{170}$ Id. (quoting Commissioner v. Clark, 489 U.S. 726, 739 (1989)). But see id. at 1785-86 (Thomas, J., dissenting) (disputing the premise that the case involved an exception to a "general statement of policy" that should be narrowly interpreted).

${ }^{171}$ See J.R. PIASECKI, HORIZON HOUSE INST. FOR RESEARCH AND DEV., COMMUNITY RESPONSE TO NEIGHBORHOOD-BASED RESIDENTIAL SERVICES FOR THE PSYCHOSOCIALly Disabled; Preliminary Results OF A NATIONAL SURVEY (1975) (finding that $34 \%$ of residential care program directors had met with community resistance); Richard Hogan, Managing Local Government Opposition to Community-Based Residential Facilities for the Mentally Disabled, 25 COMMUNITY MENTAL HEALTH J. 33, 36 (1989) (surveying the response of local government officials to residential care facilities and concluding that municipal officials expressed opposition to such programs $31 \%$ of the time when approached by the program itself and $60 \%$ of the time when approached by someone other than the program); Donald E. Weber, Neighborhood Entry in Group Home Development, 57 CHILD WELFARE 627, 637 (1978) (finding that moderate or intensive resistance to group homes develops in roughly three out of four cases).

${ }_{172}$ See Michael Dear, Understanding and Overcoming the NIMBY Syndrome, $58 \mathrm{~J}$. AM. PLAN. Ass'N 288, 288-89, 291-94 (1992) (focusing on the siting of human service facilities in the face of local opposition and ranking levels of community opposition by residence type). See generally MICHAEL WINERIP, 9 HIGHLAND ROAD (1994) (telling the story of a group home for the mentally ill and detailing the vehement public opposition to it); Malcolm Gladwell, Backlash of the Benevolent: Cities Lose Patience Treating the Troubled at Home, WASH. POST, Jan. 22, 1995, at A1, A18 (discussing decreasing "civility" and increasing community exclusion in New York City).

${ }^{173}$ See, e.g., John Leo, A Crime If Neighbors Don't Want Addicts Next Door?, ORLANDo 
in town halls. ${ }^{174}$ With crude political pressure and sophisticated zoning ordinances as the weapons of choice, group homes for recovering substance abusers are extremely vulnerable. ${ }^{175}$

\section{Why Communities Oppose Group Homes for Recovering Substance Abusers}

People who live in the communities that oppose group homes for recovering substance abusers generally do not hate disabled persons and are usually glad that those with alcohol and drug addictions want to reform themselves and contribute to society. They just do not want such undesirables living nearby. ${ }^{176}$

Vehement and pervasive local opposition to group homes for recovering substance abusers results from fear that is very real and very complex. Communities claim that the presence of group homes will cause crime rates to increase and drugs to become more prevalent. ${ }^{177}$ They fear that group homes will make property

SENTINEL, Aug. 25, 1994, at A13 (editorial) (criticizing HUD enforcement of the FHAA); Paul C. Roberts, Clinton Team Launches Attack on Single-Family Residential Neighborhoods, HOUSTON CHRON., Mar. 21, 1995, at A21 (describing FHAA enforcement in single-family residential neighborhoods as extremist).

${ }^{174}$ See, e.g., United States v. Borough of Audubon, 797 F. Supp. 353, 360-61 (D.N.J. 1991) (describing discriminatory statements made by local residents and municipal officials at a town meeting regarding the zoning of an Oxford House), aff'd, 968 F.2d 14 (3d Cir. 1992).

${ }^{175}$ See Dear, supra note 172 , at 290 ("Concerns about personal security are more common in response to certain client groups than to others. . . Unsurprisingly, substance abusers ... figure prominently in this category."); Phyllis Solomon, Analyzing Opposition to Community Residential Facilities for Troubled Adolescents, 62 CHILD WELFARE 361, 361-62 (1983) (listing techniques used to exclude group homes). Techniques for excluding group homes take a variety of forms. See, e.g., Patrick Cooke, Halfway Home, 5 IN HEALTH 88, 88-90 (1991) (describing opposition to a 10person group home that took the form of inflammatory posters and rumor); For This Home, Sherman Street Is the Wrong Backyard, RockY MouNTAIN NEwS, Aug. 21, 1994, at $96 \mathrm{~A}$ (editorial) (opposing the siting of a group home for mentally ill substance abusers based on crime concerns).

${ }^{176}$ See, e.g., Louis R. Carlozo, Oxford House Wins More Time: Group Home May Open to Residents, PHILA. INQUIRER, Mar. 26, 1992, Neighbors, at 3, 10 (quoting the Mayor of Cherry Hill Township, Susan Bass Levin, as saying, "I think we need to address the problems of drug and alcohol abuse but [an Oxford House in Cherry Hill] is not the answer"); Mitra, supra note 1, at 1 (quoting one town resident who opposed the siting of an Oxford House as saying, "Why here?. . . This is not a neighborhood where this belongs").

${ }^{177}$ The biggest reason why communities oppose group homes for recovering substance abusers is that they fear that such programs will attract crime and drugs and, in turn, will jeopardize neighborhood children. See Solomon, supra note 175, at 364-65 (noting that the most frequently given reason for opposition in all categories of group homes is that their residents make the neighborhood more dangerous); 
values plummet, ${ }^{178}$ and they fear that group homes imperil family values and destroy community character. ${ }^{179}$

When the debate is specifically focused on group homes for recovering substance abusers, the opposition becomes especially vehement. ${ }^{180}$ Yet, these concerns are unfounded. Crime and drugs do not inundate neighborhoods that include group homes for recovering substance abusers. ${ }^{181}$ Property values do not

Wahl, supra note 42, at 253-55 (classifying public perceptions of the potential impact of group homes on communities and including in the listing the categories: "Neighborhood crime," "Distressing incidents," "Neighborhood Appearance," "Resident Safety," and "Experience of Children"); see also Borough of Audubon, $797 \mathrm{~F}$. Supp. at $361 \mathrm{n} .8$ (noting the testimony of one local resident who opposed the establishment of a group home for recovering substance abusers based on drug concerns).

${ }^{178}$ See, e.g., Wahl, supra note 42, at 253-54 (classifying public perceptions of the potential impact of group homes on communities and including in this listing the concerns: "Outside Appearance of Home," "Inside Appearance of Home," "Appearance and behavior of residents," "Neighborhood traffic," and "Property values"); Arlene Zarembka, A Neighborhood Big Enough for All, ST. Louis POST-DISPATCH, Sept. 19,1994 , at $3 \mathrm{~B}$ (discussing the opposition of residents in Palatine, Illinois to the siting of an Oxford House); see also DENIS J. BRION, ESSENTIAL INDUSTRY AND THE NIMBY PHENOMENON 179-80 (1991) (describing public concern regarding the threatened devaluation of property values).

${ }^{179}$ See Dear, supra note 172, at 290 ("Residents worry that their enjoyment of the neighborhood will be undermined by the clients and that certain clients will be a bad influence on children and young people."); Solomon, supra note 175, at 364 (stating that one reason given for opposition to group homes is that they do not belong in family neighborhoods). This finding is supported by accounts of statements made in public meetings, in newspaper editorials, and during interviews with local residents. See, e.g., Borough of Audobon, 797 F. Supp. at 359-61 (describing the discriminatory comments made at a town meeting regarding the siting of an Oxford House); Leo, supra note 173, at A13 (criticizing HUD for becoming involved in local zoning disputes involving substance abusers); Mitra, supra note 1, at 1 ("We don't want transients living in the community, that's all.").

${ }^{180}$ Social scientists have ranked group homes in order of their social acceptance. In this hierarchy, recovering substance abusers along with persons with AIDS are least welcome. See Dear, supra note 172, at 291.

${ }^{181}$ In principle, the FHAA denies statutory protection to current addicts and the Anti-Drug Abuse Act and Oxford House rules strictly prohibit any and all use of alcohol and drugs. All group homes receiving funding under the Anti-Drug Abuse Act and all Oxford Houses are strictly prohibited from serving people who are not well on the road to recovery. See 42 U.S.C. $\$ 300 x-25$ (Supp. V 1993); see also MoLLOY, supra note 4, app. C at 5-6 (delineating Oxford House relapse rules which are extraordinarily stringent).

In practice, hard facts indicate that group homes for recovering substance abusers cause no increase in crime. Extensive research data support the notion that people with disabilities who live in group homes, including recovering substance abusers, are arrested less frequently than members of the general public. See R. LUBIN ET AL., Living Alternatives RESEARCH PROJECT, THE LikelihoOD OF POLICE Contacts with Developmentally Disabled PERSONS IN COMmunITy ResidenCes 
plunge. ${ }^{182}$ Community character remains intact. ${ }^{183}$ Indeed, research indicates that such programs improve the communities in which they operate. ${ }^{184}$

Although community fear regarding group homes for recovering substance abusers is not based upon fact, it is not irrational. The

(1982) (studying 368 community residences in New York and finding that mentally retarded persons in community residences are arrested at far lower rates than members of the general public and further finding that group-home residents are rarely involved with the police), cited in Robert L. Schonfeld, "Five-Hundred-Year Flood Plains" and Other Unconstitutional Challenges to the Establishment of Community Residences for the Mentally Retarded, 16 FORDHAM URB. L.J. 1, 9 n.35 (1988); see also Oxford House-C v. City of St. Louis, 843 F. Supp. 1556, 1570 (E.D. Mo. 1994) (discussing studies performed by zoning experts that indicate that such programs do not have an impact on crime and safety); Tom Pelton, Federal Law Is Letting Group Homes Tiptoe into Town: New Rules Open Door for Mentally Disabled, CHI. TRIB., Oct. 4, 1994, at 1, 16 (noting that studies have shown that group homes do not raise crime rates).

${ }_{182}$ Public concern about decreased property values resulting from the presence of group homes is equally unfounded. Numerous empirical studies demonstrate that community housing for people with all sorts of disabilities does not affect the market value or marketability of neighboring homes. Such examinations have measured the length of time the home remained on the market, the sale price as a percentage of the list price, the rate of turnover, and the rate of the property's appreciation. See George Galster \& Yolanda Williams, Dwellings for the Severely Mentally Disabled and Neighborhood Property Values: The Details Matter, 70 LAND EcoN. 466, 466 (1994) (noting the widespread opinion of researchers, based on the results of numerous studies, that group housing for mentally disabled residents does not reduce the value of neighboring properties); see also Katherine M. Boydell et al., The Effect of Group Homes for the Mentally Ill on Residential Property Values, 40 HOSP. \& COMMUNITY PSYCHIATRY 957, 958 (1989) (reporting the results of a study finding that "the presence of a group home for the psychiatrically disabled in a residential neighborhood had no adverse effect on property values"); Stephen Farber, Market Segmentation and the Effects on Group Homes for the Handicapped on Residential Property Values, 23 URB. STUD. 519, 524 (1986) (concluding that group homes positively affect housing prices in below-average socioeconomic submarkets and that group homes have no observable or statistically significant effect in high socioeconomic markets); Carey $\mathrm{S}$. Ryan \& Ann Coyne, Effects of Group Homes on Neighborhood Property Values, 23 MENTAL RETARDATION 241, 244-45 (1985) (determining that the presence of a group home did not adversely affect the length of time a house remained on the market, the rate of turnover in a neighborhood, or the sale price as a percentage of the list price); Wahl, supra note 42, at 255 (finding that although the majority of survey respondents expected that a group home would unfavorably affect property values and home sales, a majority found no such unfavorable effect when a group home was actually placed in their neighborhoods).

${ }^{183}$ See Diana Arens, What Do the Neighbors Think Now? Community Residences on Long Island, New York, 29 COMMUNITY MENTAL HEALTH J. 235, 239 (1993) (reporting findings from a study that showed only $2 \%$ of people in neighborhoods with group homes felt negatively about the effects on the neighborhood after two to three years).

${ }^{184}$ See Boydell et al., supra note 182, at 958 (stating that group homes may upgrade neighborhoods through renovations and commenting that "[s]uch facilities are frequently in better structural and physical condition than other homes in the surrounding area"). 
frequently expressed concern that group homes simply "don't belong" in their communities is founded upon very natural phenomena. Neighborhoods often operate as extraordinarily defensive social organizations, mobilizing rapidly when something threatens their character and stability. ${ }^{185}$ When community members feel threatened, they exhibit protectionist attitudes and exercise oppositional tactics to defend their turf. They try to exclude the sources of their concern. ${ }^{186}$

Such fears are based on a variety of sociological and psychological principles, particularly heuristics. Outsiders seeking entry into a neighborhood not only epitomize difference, which is frequently perceived as threatening in itself, but they also represent disease and current social ills. ${ }^{187}$ In this context, group homes are seen as emblems of incapacity, providing shelter for "conniving malingerers" and deviants. ${ }^{188}$

Local opposition to outsiders based on such perceptions is, indeed, a phenomenon on the rise. Private, fenced-in communities establish their own regulations and avoid municipal ordinances. ${ }^{189}$

${ }^{185}$ See generally Harold A. Ellis, Neighborhood Opposition and the Permissible Purposes of Zoning, 7 J. LAND USE \& ENVTL. L. 275, 275 (1992) (discussing the factors that influence neighborhood opposition).

${ }^{186}$ See Dear, supra note 172, at 290-91 (discussing NIMBYism in terms of human services planning); see also Peter Margulies, Building Communities of Virtue: Political Theory, Land Use Policy, and the "Not in My Back Yard" Syndrome, 43 SYRACUSE L. REV. 945,953 (1992) (describing community fear as a method of segregating marginalized groups that replaced more traditional methods such as committing people to mental health institutions).

${ }^{187}$ See Margulies, supra note 186, at 953, 955 (explaining the mental processes used by members of neighborhoods when group homes are sought to be established in them).

Defects in human inference account for much popular opposition to community human service facilities. Human inference runs on heuristics and biases which guide and simplify thought. Unfortunately, these devices magnify the perceived risks of association with those labeled as outsiders, including human service clients.

Id. at 954-55 (footnote omitted); see also Gladwell, supra note 172, at A18 (commenting that advocates for the disabled assert that people at the margins of society serve as scapegoats for the larger problems of society).

${ }^{188}$ Margulies, supra note 186 , at 955 .

${ }^{189}$ See Timothy Egan, Many Seek Security in Private Communities: The Serene Fortress, N.Y. TIMES, Sept. 3, 1995, at 1 (describing the rapid growth of private communities, encircled by gates and fences and nearly always governed by "a thicket of covenants, codes, and restrictions ${ }^{\prime \prime}$; $i d$. at 1,10 (stating that enclosed private communities are the fastest growing residential areas in the nation, with nearly 4 million inhabitants, and that 28 million Americans currently live in areas governed by private community associations, which number is expected to double within the next decade). 
Laws now require neighbor notification when sex offenders move into communities. ${ }^{190}$ One community service expert observed: "The last two or three years has been the turning point. It's no longer 'not in my backyard.' It's now an opposition to everything everywhere by everyone." 191

\section{How Communities Use the Zoning Process to Exclude Group Homes for Recovering Substance Abusers}

Neighborhood opposition is perpetuated by the legitimate purposes of zoning itself. Originally, zoning and local land-use regulations were simply thought of as a method for regulating the physical aspects of a municipality's environment. ${ }^{192}$ They have, however, evolved into something far greater. Rather than mere mechanisms for minimizing the negative physical features in a particular community, local zoning now defines good and bad neighborhoods and determines who can and cannot reside in them. Specifically, zoning laws seek to protect property values and regulate the socioeconomic environment of a community. ${ }^{193}$ They establish whether neighborhoods are residential, commercial, or industrial. They determine whether homes are detached, multifamily, apartments, mobile, highly concentrated, set-back, large, tall, or ugly. On a more theoretical level, local land-use ordinances operate

${ }^{190}$ See, e.g., KAN. STAT. ANN. \$§ 22-4909, 45-221(a)(29)(C) (Supp. 1994) (requiring that lists of all sex offenders be made available to the public); LA. CODE CRIM. Proc. ANN. art. 895(H) (West Supp. 1994) (requiring all sex offenders to mail notices to all neighbors within a one-mile radius in rural areas and a three-block radius in urban areas, and further requiring that the offender must publish the information in a local journal for two days); N.J. STAT. ANN. \$§ 2C:7-1 to :7-8 (West 1995) ("Megan's Law") (establishing a three-tiered scheme ranking the sex offenders' risk of recidivism and varying the level of community notification based upon their ranking); WASH. REV. CODE ANN. \$ 4.24.550 (West Supp. 1995) (authorizing public agencies "to release relevant and necessary information regarding sex offenders to the public when the release of the information is necessary for public protection").

${ }^{191}$ Gladwell, supra note 172, at A18.

192 See J. Gregory Richards, Zoning for Direct Social Control, 1982 DUKE L.J. 761, 762-63 (describing the original goals of zoning); see also Village of Euclid v. Ambler Realty Co., 272 U.S. 365, 390-96 (1926) (considering the constitutionality of a municipality's zoning plan and focusing on the physical problems, such as lack of sunlight and an increase in traffic and noise, when evaluating the scheme's validity).

${ }^{193}$ See Anne B. Shlay \& Peter H. Rossi, Keeping Up the Neighborhood: Estimating Net Effects of Zoning, 46 AM. SOC. REV. 703, 717 (1981) (examining the political dimension of zoning, describing how it works, and finding that "[z]oning is an important, local, political method for shaping the housing and population composition of metropolitan neighborhoods"). 
as the preeminent symbol of social identification ${ }^{194}$ and perhaps the most effective mechanism for direct social control. ${ }^{195}$

The enforcement of local zoning laws can, in fact, be characterized as the ideal manifestation of civic responsibility ${ }^{196}$ and participatory democracy. ${ }^{197}$ The process of zoning encourages a distinct sense of local control. This is achieved through the election or appointment of local board members, the dividing of municipalities into distinct land-use categories, the establishment of procedural rules regarding the determination of appropriate and unacceptable land uses, and the public hearing and notice process. Using these means, communities have become entrenched in the notion that the establishment and enforcement of zoning laws is their specific bailiwick for mobilization. ${ }^{198}$ This, coupled with a process characterized by fragmented, and often random decisionmaking, ${ }^{199}$ serves to solidify zoning as a winner-take-all method for banning that which cannot be prohibited directly. ${ }^{200}$

194 See Martha Minow, Making All the Difference: Inclusion, Exclusion, AND AMERICAN LAW 214-15 (1990) (using local opposition to group homes as a method of modeling attitudes toward difference); see also Lea S. VanderVelde, Local Knowledge, Legal Knowledge, and Zoning Law, 75 IowA L. REv. 1057, 1074 (1990) ("From location flows the social organization of where your children attend school, where you walk your dog, and where you buy your groceries. Zoning assures that others who you are most likely to bump into are on your same social level.").

${ }^{195}$ See Richards, supra note 192, at 765 (examining land regulation as a method for excluding or including on the basis of relatively immutable characteristics as defined by an ordinance); see also VanderVelde, supra note 194, at 1060 (commenting that " $[t]$ he zoning process, like selecting a place to live, is 'an important way in which people assert a sense of mastery and control over their environment" (quoting A. RAPOPORT, HUMAN ASPECTS OF URBAN FORM: TOWARDS A MAN-ENVIRONMENT APPROACH TO URBAN FORM AND DESIGN 368 (1977))).

${ }^{196}$ See Margulies, supre note 186, at $945-46$ ("Bitter opposition to facility siting mocks attempts to revive civic republican participation in deliberation about the common good, and clashes with liberal precepts of fairness and equality." (citations omitted)).

${ }^{197}$ See BRION, supra note 178, at 30-47 (describing NIMBYism as a model of participatory democracy); see also Frank J. Popper, LULUs and Their Blockage: The Nature of the Problem, The Outline of the Solutions, in CONFRONTING REGIONAL CHALLENGES: APPROACHES TO LULUS, GROWTH, AND OTHER VEXING GOVERNANCE PROBLEMS 13, 16 (Joseph F. DiMento \& LeRoy Graymer eds., 1991) (explaining locally unwanted land-uses as an indication "that the Untied States is transforming itself into a ... more democratic ... society").

${ }^{198}$ See Ellis, supra note 185, at 275-76 (recognizing zoning as a legitimate exercise of police power and neighborhood opposition as an integral part of the process).

${ }^{199}$ See VanderVelde, supra note 194, at $1067-72$ (reviewing the activities of local zoning boards); see also Philip D. Tegeler, Housing Segregation and Local Discretion, 3 J.L. \& POL'Y 209, 212 (1994) (noting widespread delegation of responsibility for landuse regulation to municipalities).

${ }^{200}$ See John D. Hutcheson, Jr. \& James E. Prather, Community Mobilization and 
Indeed, for community housing dedicated to the rehabilitation of recovering drug addicts, such laws have functioned too effectively. With distressing frequency, they have served to impede the establishment of group homes and to perpetuate discrimination against recovering substance abusers. Faced with fervent community opposition, much-needed residential drug rehabilitation programs, along with numerous other types of community-based programs, frequently lack sufficient resources to win in town hall or in court, and, as a result, they must either give up on the sites or relocate in far less suitable communities. ${ }^{201}$

The most important and problematic obstacles confronting group homes for recovering substance abusers are single-family home zoning ordinances. Located at the apex of the "Euclidean Pyramid," 202 single-family residential communities often display the most vehement opposition to the siting of Oxford Houses and similar programs. To keep recovery houses out, communities accommodating single-family homes employ a variety of zoning techniques. ${ }^{203}$ Sometimes, these involve the direct regulation of housing for persons with disabilities. ${ }^{204}$ More often, however, they appear as facially neutral statutes, specifically, notice requirements

Participation in the Zoning Process, 23 URB. AFF. Q. 346, 347 (1988) (describing the process as one with clearly identifiable winners and losers in which, from the community's perspective, decisions go either "for them" or "against them").

201 See Margulies, supra note 186, at 962-63.

Poor communities' lack of access to this repertoire of resistance reinforces market tendencies to concentrate human service facilities in low-income neighborhoods. [In these neighborhoods,] real estate is less valuable. . . . Ironically, communities used as "dumping grounds" tend to have fragile support systems which are least able to meet the needs of citizens receiving services.

Id. (citations omitted); see also Hutcheson \& Prather, supra note 200, at 346-49 (discussing consistent findings that community participation in zoning is negatively associated with community affluence).

${ }^{202}$ See Schlay \& Rossi, supra note 193, at 705 ("Euclidean zoning designated a rank ordering of land-use desirability to guide local governments in their decisions. Zoning's primary purpose was specified as protecting neighborhoods of single-family dwellings, placed at the top of the priority pyramid. "); VanderVelde, supra note 194, at 1063 n.30 (commenting that single-family detached housing is at the "pinnacle of the zoning law pyramid" and that "all other forms of residential units often are evaluated for their capacity to harm single-family residential housing").

${ }^{203}$ See Schonfeld \& Stein, supra note 116, at 307 (describing the discriminatory impact of such ordinances).

${ }^{204}$ See, e.g., infra notes $220-26$ and accompanying text (describing a zoning ordinance that requires 24-hour supervision of group homes and the establishment of a community advisory committee to facilitate a neighborhood complaint process for such programs). 
or similar conditions that particularly affect group residences for handicapped persons. ${ }^{205}$ These ordinances often seem innocuous, and any judicial intervention may appear to be over-reaching. ${ }^{206}$ Yet zoning ordinances are often applied to group homes serving people with disabilities in ways that are far from benign, making close judicial scrutiny necessary. By applying land-use regulations that restrict the definition of the family and limit access to residential neighborhoods, municipalities have unlawfully established ways to discriminate against group homes for recovering substance abusers while maintaining the appearance of exercising legitimate local control.

\section{B. Judicial Tolerance of Zoning Laws That Exclude Group Homes}

Municipal authority must be curtailed when it infringes upon the rights of disabled persons. Yet, for group homes for recovering substance abusers, the courts have failed to fulfill this responsibility. This is not the result of judges lacking the tools for effective enforcement, for the FHAA provides a powerful arsenal of legal remedies. ${ }^{207}$ This is not the result of the courts turning a blind eye, for there are many instances in which local laws that perpetuate housing bias are successfully invalidated. ${ }^{208}$ Rather, courts fail to protect effectively the housing rights of group homes for recovering

${ }^{205}$ See, e.g., infra notes 227-39 (discussing Palatine, Illinois's zoning ordinance requiring special-use approval for establishing group homes in single-family residential neighborhoods).

${ }^{206}$ See The Fair Housing and Free Speech Act of 1995, S. 1132, 104th Cong., 1st Sess., discussed in 141 CONG. REC. S12,079 (daily ed. Aug. 9, 1995) (statement of Sen. Faircloth) (proposing provisions that would overrule the Supreme Court's decision in Edmonds, and stating that "decisions about zoning should be made in cities and towns and not in Washington"). This concern drew opposition to the FHA prior to its original passage in 1968. See Leland B. Ware, New Weapons for an Old Battle: The Enforcement Provisions of the 1988 Amendments to the Fair Housing Act, 7 ADMIN. L.J. AM. U. 59, 71-72 (1993) ("Opponents of the fair housing bill claimed that the legislation would interfere impermissibly with the right of citizens to control the disposition of their property.").

${ }^{207}$ See 42 U.S.C. \$§ 3612-3614 (enumerating mechanisms for enforcement through HUD, private parties, and the U.S. Attorney General).

${ }^{203}$ See, e.g., Potomac Group Home Corp. v. Montgomery County, 823 F. Supp. $1285,1296-97$ (D. Md. 1993) (invalidating a neighbor-notification requirement because it created an explicit classification based on a disability without any legitimate justification); Oxford House, Inc. V. Township of Cherry Hill, 799 F. Supp. 450, 465 (D.N.J. 1992) (enjoining enforcement of a local zoning ordinance that would prevent prospective residents of a group home for recovering substance abusers from moving in). 
substance abusers because they erroneously interpret one test for proving FHAA violations-the "reasonable accommodations" clause.

When it passed the FHAA, Congress intended that communities be prohibited from employing zoning ordinances and local housing policies in a manner that denies people with disabilities access to housing on par with that of those who are not disabled. It intended that when laws fail to do this, they must be invalidated or rewritten to meet the residential needs of handicapped persons. This is the meaning of "reasonable accommodations." 209 "Yet, courts consistently fail to recognize this obligation. Rather than recognize the "reasonable accommodations" clause as an affirmative obligation, courts employ a balancing test when examining special permit proceedings, and weigh community interests against the statutorily protected rights of recovering substance abusers. In turn, they uphold special permit proceedings, notice requirements, and other ordinances that operate to exclude group homes for recovering substance abusers.

\section{Disability-Based Classifications}

In a world without the FHAA, municipalities could easily prevent group homes for recovering substance abusers from entering their communities by enacting zoning ordinances that explicitly distinguish between disabled and nondisabled persons. From a town's perspective, such an ideal provision would directly and completely preclude recovery houses from entering singlefamily residential neighborhoods. Yet, the FHAA does exist, and courts usually find that such measures clearly violate it. But the FHAA is not uniformly successful in this respect. Serious problems remain when courts assess laws that explicitly treat disabled persons differently than others.

The basic rule regarding disability-based classification is set forth in Horizon House Developmental Services, Inc. v. Township of Upper Southampton, ${ }^{210}$ which states that $[\mathrm{a}] \mathrm{n}$ ordinance that uses a discriminatory classification[] is unlawful in all but rare circum-

${ }^{209}$ See infra part IV.A (describing an alternative interpretation of the "reasonable accommodations" clause based upon the concept of affirmative obligation).

210804 F. Supp. 683, 700 (E.D. Pa. 1992) (granting declaratory and injunctive relief to a residential program for persons with mental retardation from an ordinance setting forth a 1000-foot spacing requirement for all group homes), affd, $995 \mathrm{~F} .2 \mathrm{~d}$ 217 (3d Cir. 1993). 
stances. ${ }^{211}$ Such a violation can be established in one of three ways: (1) by demonstrating that the challenged statute has no legitimate purpose; (2) by showing that its classifications were adopted on the basis of handicap; or (3) by proving that the statute had a discriminatory effect. ${ }^{212}$ That same year, the Sixth Circuit decided the leading case, Marbrunak, Inc. v. City of Stow. ${ }^{213}$ This decision invalidated a zoning ordinance that imposed onerous safety requirements on programs serving the disabled in residential neighborhoods. ${ }^{214}$ Another significant case, more recently decided, is Potomac Group Home Corp. v. Montgomery County. ${ }^{215}$ Citing Marbrunak and Horizon House, it held that a neighbor-notification requirement created to apply explicitly to people with disabilities was unjustified and in violation of the FHAA. ${ }^{216}$

Unfortunately, for group homes for recovering substance abusers, the fact that most courts find disability-based classifications to be unlawful offers cold comfort. Two decisions, one of which is a Tenth Circuit case decided this year, indicate that such laws are sometimes permissible.

Until recently, the only case to validate zoning restrictions applicable specifically to group homes was Familystyle of St. Paul, Inc. v. City of St. Paul, ${ }^{217}$ in which the Eighth Circuit upheld state and municipal dispersal requirements for group homes serving the mentally ill because it believed that the provision promoted community integration of people with disabilities. ${ }^{218}$ It is interesting to note, however, that this decision was reached in spite of the fact that the organization providing the housing believed that the statute harmed, rather than benefitted, people with disabilities. ${ }^{219}$

211 Id. at 693.

${ }^{212}$ See id. (citing United States v. Schuylkill Township, No. 90-2165, 1990 WL 180980 , at *6 (E.D. Pa. Nov. 16, 1990)).

213974 F.2d 43 (6th Cir. 1992) (invalidating stringent safety standards applicable only to homes serving people with developmental disabilities).

${ }^{214}$ See id. at 47-48 (finding safety requirements to violate the FHAA on the basis that they were unduly burdensome and not specifically tailored to the particular disabilities of the residents):

215823 F. Supp. 1285 (D. Md. 1993) (striking a public notice requirement specifically applicable to group homes for people with disabilities).

216 See id. at 1296, 1302.

217923 F.2d 91 (8th Cir. 1991).

${ }^{218}$ See id. at 94-95 ("The state's group home dispersal requirements are designed to ensure that mentally handicapped persons needing residential treatment will not be forced into enclaves of treatment facilities that would replicate and thus perpetuate the isolation resulting from institutionalization.").

${ }^{219}$ See id. at 93 ("Familystyle argues that the Minnesota and St. Paul dispersal 
The second and more recent case calling into question the legality of disability-based classifications is Bangerter v. Orem City Corp. ${ }^{220}$ In this case, a municipality enacted two facially discriminatory rules: it required that a group home for the mentally handicapped be supervised on a twenty-four hour basis; and it also required that a community advisory committee be established to address all complaints and concerns of the program's neighbors. ${ }^{221}$ Although the Tenth Circuit found that the group home established a prima facie case of intentional discrimination under the FHAA, ${ }^{222}$ reversing the lower court's dismissal of the group home's complaint, it remanded the case for further review. ${ }^{223}$ In so doing, the Tenth Circuit severely narrowed the group home's ability to prove unlawful discrimination. The court explained that the town could rebut the prima facie case of intentional discrimination if it could prove that: (1) this particular group home was subjected to no more restrictions than other non-handicapped group homes in the town; ${ }^{24}$ (2) there was a public safety reason for the provisions; ${ }^{225}$ or (3) these restrictions, although explicitly

requirements are invalid because they limit housing choices of the mentally handicapped and therefore conflict with the language and purpose of the 1988 Amendments to the Fair Housing Act.").

${ }^{220} 46$ F.3d 1491 (10th Cir. 1995).

221 As explained in the court's opinion:

In granting the permit ... the Council imposed two conditions on the group home that Bangerter alleges violate the FHAA:

[1] [the group home operator] had to ensure the City that the residents were properly supervised on a twenty-four-hour basis; [and]

[2] [the group home operator] had to establish a community advisory committee through which all complaints and concerns of the neighbors could be addressed.

Id. at 1496 (alterations in original).

${ }_{222}$ See id. at 1502 ("We agree with the district court's initial conclusion that

Bangerter made out a prima facie case of discrimination under the FHAA."). ${ }_{223}$ See id.

224 The court stated:

On remand, Bangerter will have to introduce evidence to support his allegations of discrimination. Besides proving sufficient concrete personal injury to maintain standing, Bangerter must support his basic claim that his group home was subjected to conditions not imposed on other group homes in Orem that were permitted in areas zoned... for single-family residences. If Bangerter cannot show that group homes for the non-handicapped are permitted in Orem without requirements like the 24-hour supervision or neighborhood advisory committee requirements, he will have failed to show that he has suffered differential treatment when compared to a similarly situated group, and his claims will fail under the FHAA.

See id.

${ }_{225}$ See id. at 1503-04 (commenting that on remand the court should investigate 
discriminatory, "are really beneficial to, rather than discriminatory against, the handicapped." 226

Familystyle and Bangerter raise the possibility of enormous FHAA loopholes. They are a far cry from the "all but rare circumstances" exception suggested in Horizon House. These seemingly "rare circumstances ${ }^{n}$ occur with distressing frequency. If they can arise whenever a community can offer some benign justification for facially discriminatory ordinances, these "rare circumstances" may, in fact, drastically curtail the scope of the FHAA with regard to group homes for recovering substance abusers.

\section{Special-Use Permitting Procedures}

Facially discriminatory zoning laws must be fairly sophisticated if courts are to uphold them. The same is true for facially neutral ordinances. This is why communities opposing group homes for recovering substance abusers increasingly rely on subtle and complex modes of segregation. For anyone who doubts how creative communities can be when they want to exclude group homes for recovering substance abusers, she need only examine the recent special-use permitting procedures employed by cities and towns to discriminate against recovering substance abusers in singlefamily residential zones. ${ }^{227}$ Sadly, the courts too often uphold these procedures. Two especially stunning blows were delivered directly to Oxford Houses: United States v. Village of Palatine ${ }^{228}$ and Oxford House, Inc. v. City of Virginia Beach. ${ }^{229}$

Recovering substance abusers can only live in an R-1B Single Family District in Palatine, Illinois, if they are part of a "family" or live in a "group home." For zoning purposes within the municipality, a "family" means only: (1) a nuclear family plus not more than three relatives, or (2) a group of up to three nonrelatives. Under

whether the Orem supervision requirement was on- or off-site, and how "oppressive or benign it might have been").

${ }^{226}$ Id. at 1504 (emphasizing that the FHAA only makes it illegal to discriminate against handicapped persons).

${ }_{227}$ See, e.g., Lynne Carrier, Council Seeks More Control of Group Homes, SAN DiEgo DAILY TRANSCRIPT, Oct. 11, 1995, at A1 (describing how the city council earmarked $\$ 26,000$ to pinpoint the location of group homes, approved a voluntary "good neighbor" policy to "prepare the community for any new group homes that plan to locate in their vicinity, ${ }^{n}$ and established a requirement that all group homes with seven or more beds obtain a conditional-use permit involving public notification).

22837 F.3d 1230 (7th Cir. 1994).

${ }^{229} 825$ F. Supp. 1251 (E.D. Va. 1993). 
the zoning ordinance, a "group home" must have a paid professional support staff. ${ }^{230}$ Residents of Oxford House-Mallard, situated in this type of district, met neither of these standards. As a result, this group of eleven unrelated recovering alcoholics and addicts violated local zoning restrictions when they moved in. Subsequent to their occupancy, Palatine amended its zoning ordinance to allow them to reside within the R-1B zone, not as of right, but through the process of special-use approval. Oxford House, as a matter of principle, refused to initiate this procedure, and as a result, Palatine cited it for violating the municipal zoning ordinance. ${ }^{231}$

If Oxford House had complied with the special-use process and participated in this new procedural requirement, there still would have been no assurance that such municipal approval would be awarded. Merely to be considered, Oxford House residents would have been forced to subject themselves to a lengthy, contentious public hearing process and would have been scrutinized by a community that had already expressed deep-seated opposition to their presence. ${ }^{232}$ They were unwilling to do so and sued Palatine for failure to make reasonable accommodations under the FHAA by requiring them to undergo scrutiny not otherwise required of those

${ }^{230}$ See Palatine, 37 F.3d at 1231-32.

${ }^{231}$ See MOLLOY, supra note 4, at 16; see also Palatine, 37 F.3d at 1232 ("As a matter of practice, Oxford House, Inc. does not seek prior approval of zoning regulations before moving into a residential neighborhood. It considers itself no different from a biological family and its members just move into any suitable house . . . .").

${ }^{232}$ The Seventh Circuit's opinion in Palatine is completely silent regarding Palatine residents' opposition to the establishment of the Oxford House. The unreported lower court's "Report and Recommendation on Plaintiff's Motion for a Preliminary Injunction," however, is not. It notes, in part:

Shortly after Oxford House signed the lease on the Mallard Drive property and before any residents moved into the residence, ... the Village's Planning and Zoning Administrator ... informed [the landlord] that the Village had 'received numerous complaints about a halfway house for recovering alcoholics being proposed' at her residence. ... .

$\ldots \ldots$

... [A village council member] suggested that due to political pressure, Oxford House should keep the number of residents in the house to four and not fill the house until after the scheduled municipal spring elections. He said that Oxford House would still have to apply for a special use permit and a text amendment. ... [The same council member] stated that "it was in [Oxford House's] best interest to make-to make friends with the neighbors because if the neighbors came out and opposed [the] applications, then the applications would be denied."

United States v. Village of Palatine, No. 93-C 2154, 1993 WL 586699, at *7-8 (N.D. IIl. Sept. 28, 1993). 
living in the single-family residential zone. ${ }^{233}$ Unfortunately, they lost.

The Seventh Circuit upheld the zoning ordinance and further held that Oxford House residents could only bring a valid FHAA claim after they completed the formal special-use permitting process. ${ }^{234}$ Palatine's president, Rita Mullins, like so many in her town, was thrilled. Palatine had successfully forced the group home to submit to its special-use permit process. It had won a victory for proponents of local control. Mullins was able to attend the annual National League of Cities Conference in Minneapolis and boast of her success in fighting for the community's rights. ${ }^{235}$

Palatine clearly illustrates a flawed judicial interpretation of the FHAA and, in particular, incorrect application of its "reasonable accommodations" provision. Indeed, the court's reasoning is almost as disturbing as the Mullins's actions. Responding to Oxford House's claim that the very invocation of the special-use permitting process failed to reasonably accommodate the needs of individuals protected under the FHAA, the court balanced each party's interests, weighing the need for public input against the burden public hearings would place on the program's residents. ${ }^{236}$ The Seventh Circuit sympathized with program residents who would be scrutinized and stigmatized by the hearing process, in spite of Palatine's assurances that they had no legal obligation to attend the public meetings. ${ }^{237}$ Despite this concern, the court decided that

${ }^{233}$ See Palatine, 37 F.3d at 1233 ("Plaintiff argues that requiring the residents of Oxford House-Mallard to undergo a public hearing on their proposed special use would subject them to 'a firestorm of vocal opposition within the neighborhood,' that in turn would stigmatize the residents and increase the chances of a relapse.").

${ }^{234}$ See id. at 1234 (noting that the zoning process, including the hearing and conditional-use permit process, enables the city to reasonably accommodate the group home, rather than finding that the permitting hearings are themselves at the root of the problem).

${ }_{235}$ See Sarah Talalay, Palatine's Win Based on Process, CHI. TRIB., Oct. 13, 1994, § 2 , at 1 (noting that Mullins was planning to take along copies of the appeals court decision with her to the conference in December, 1994).

${ }^{236}$ See Palatine, 37 F.3d at 1234 ("[D]etermining whether a requested accommodation is reasonable requires, among other things, balancing the needs of the parties involved. $)$.

237 The court stated:

Plaintiff argues that requiring the residents of Oxford House-Mallard to undergo a public hearing on their proposed special use would subject them to "a firestorm of vocal opposition within the neighborhood" . . . . We are also sympathetic to plaintiff's concern that even if the Oxford HouseMallard residents were not required to appear at a public meeting, such a meeting would serve to focus neighborhood scrutiny on the residence and 
because Palatine had adequately responded to the needs of other handicapped individuals on former occasions, it could risk harm to these handicapped people in the present. ${ }^{238}$ On balance, the Seventh Circuit held that public input was more important than shielding these disabled individuals from potential, even probable, harm. ${ }^{239}$

Thus, Palatine stands for the proposition that "reasonable accommodations in rules [and] policies ... when ... necessary to afford the [handicapped person] equal opportunity" ${ }^{240}$ entail promising hypothetical, rather than actual protections against discrimination. The mere existence of a purely theoretical possibility that the special-use permitting process could be employed in a nondiscriminatory fashion was sufficient reason to uphold the ordinance. The harsh realities of the special-use permitting process, along with the blatant admission that public hearings would discriminate against disabled people were completely irrelevant.

Oxford House, Inc. v. City of Virginia Beach ${ }^{241}$ was based on a relatively similar set of circumstances. Virginia Beach's zoning ordinance defines a "family" to include groups of no more than four people unrelated by blood or marriage. In order to establish any home in a single-family residence that fails this requirement, prospective residents are forced to obtain conditional-use permits. Applications for conditional-use permits must be filed with the planning director, reviewed by the planning commission, and then approved by the city council. Furthermore, Virginia Beach's zoning code requires that applicants publish notice of the request followed by a public hearing. ${ }^{242}$ As in Palatine, Oxford House refused to reduce the number of residents or apply for the conditionaluse permit. ${ }^{243}$ And, like Palatine, the Virginia Beach court incor-

stigmatize its inhabitants as recovering alcoholics.

Id. at 1233-34.

${ }^{238}$ See id. at 1234 (noting that because Palatine has a good record in responding to the needs of handicapped individuals, "it cannot be said that resort by Oxford House-Mallard to the special use procedure would be futile").

${ }^{239}$ See id. (concluding that the harm likely to befall Oxford House residents did not outweigh the municipal interest in receiving public input during the special-use permitting process).

${ }_{240} \mathrm{Id}$. at 1232 (quoting 42 U.S.C. $\$ 3604(\mathrm{f})(3)(\mathrm{B})$ ) (second alteration in original).

241825 F. Supp. 1251 (E.D. Va. 1993).

${ }^{242} \mathrm{See}$ id. at 1255 (explaining the conditional-use permit application process, including its notice and public hearing requirements).

${ }^{245}$ See id. at 1255-56 (stating that Oxford House argued that it was "not 'fair or feasible' to require [them] to apply for a conditional use permit because the 
rectly applied the "reasonable accommodations" provision of the FHAA.

Virginia Beach stated that Congress clearly did not intend federal courts to become "entangled prematurely in disputes regarding application of neutral zoning ordinances to the handicapped."244 Therefore, any obligation for group home residents to participate in public hearings could not constitute an FHAA violation. ${ }^{245}$ Yet, the Virginia Beach court went even further. It concluded that for Oxford Houses to protect themselves from the ravages of conditional-use hearing procedures, they must be able to locate specific provisions in the FHAA that insulate them from such scrutiny. ${ }^{246}$ Because such language is not explicit in the statute, the Oxford Houses were obligated to participate in the special zoning process.

Palatine and Virginia Beach provide a powerful arsenal for communities seeking to alienate rather than to integrate recovering substance abusers. Indeed, little prevents municipalities from establishing zoning ordinances in all circumstances requiring every group home for recovering substance abusers to undergo stringent notice and hearing requirements. The FHAA states that people with disabilities should be treated no differently than people without disabilities. Yet, courts uphold discriminatory zoning ordinances. They are able to do so only when they balance the interests of local authorities-interests often guided by bias, as well as by politics-against the housing rights of people with disabilities. ${ }^{247}$

application process will expose the residents 'to effectively unrestricted public scrutiny of their personal lives and histories' that 'can be expected by itself to cause plaintiff households to disintegrate'").

244 Id. at 1261.

245 See id. ("Congress obviously contemplated providing cities, among others, the opportunity to adjust their generally applicable rules to allow handicapped individuals equal access to housing. The zoning process, including the hearings on applications for conditional use permits, serves that purpose." (citation omitted)).

${ }^{246}$ See id. at 1262.

[The] plaintiffs point to no provision of the [FHAA] suggesting [that it] insulate[s] such individuals from legitimate inquiries designed to enable local authorities to make informed decisions on zoning issues. ... [I]f Congress had intended to exempt handicapped persons from participation in the usual procedural requirements of the zoning process, it could have do[ne] so expressly.

Id. But see H.R. No. 711, supra note 83, at 24 (noting that the FHAA was intended "to prohibit the application of . . . conditional or special use permits that have the effect of limiting the ability of [handicapped persons] to live in the residence of their choice"), reprinted in 1988 U.S.C.C.A.N. at 2185.

${ }^{247}$ In contrast to the Palatine and Virginia Beach decisions, one district court has 


\section{Narrow Definitions of Single-Family Residential Neighborhoods}

Some municipalities exclude group homes for recovering substance abusers by forcing those who establish and operate them to jump through the hoops of conditional-use permitting processes. Other towns deter the development of such programs by carving out other types of facially neutral exceptions in local zoning laws that have the effect of barring group homes from single-family residential neighborhoods.

Limiting the number of unrelated persons who may live together in single-family residential neighborhoods was, until recently, the favorite way for many communities to discriminate against people with disabilities. City of Edmonds v. Oxford House, Inc. ${ }^{248}$ gave the Supreme Court the opportunity to halt this tactic completely, but in the end the Court's decision provided only limited recourse for group homes for recovering substance abusers. Rather than declaring that municipal usage of maximum-occupancy limitations to restrict group-home access to single-family residential neighborhoods constitutes unlawful housing discrimination, the Court held only that local restrictions on the number of unrelated persons who may live together constitute land-use regulations rather than occupancy restrictions and are, therefore, not exempt from FHAA coverage under $\S 3607(\mathrm{~b})(1) .{ }^{249}$ Although the Court decided in favor of Oxford House, and although the ruling was warmly received by group-home advocates, ${ }^{250}$ the victory nevertheless rings somewhat hollow. ${ }^{251}$

determined that application of this balancing test would cause irreparable harm to recovering substance abusers. See Oxford House, Inc. v. Township of Cherry Hill, 799 F. Supp. 450, 464 (D.N.J. 1992). Indeed, other cases involving the housing rights of group-home residents support this claim. See Potomac Group Home Corp. v. Montgomery County, 823 F. Supp. 1285, 1290, 1296-97 (D. Md. 1993) (describing a neighborhood-notification process that provoked petitions and letter-writing campaigns in opposition and resulted in stigma to the residents of the group home); see also Stewart B. McKinney Found., Inc. v. Town Plan \& Zoning Comm'n, 790 F. Supp. 1197, 1220 (D. Conn. 1992) (concluding that subjecting residents of a facility for HIV-positive individuals to public scrutiny served to perpetuate the segregation of such citizens).

248115 S. Ct. 1776 (1995); see also supra notes 161-70 and accompanying text (discussing Edmonds and the maximum-occupancy exception).

${ }^{249}$ See Edmonds, $115 \mathrm{~S}$. Ct. at 1783.

${ }^{250}$ See, e.g., Ignacio Lobos, Group-Home Decision Hailed, SEATTLE TIMES, May 16, 1995 , at B1 (quoting a variety of supporters of the disabled and noting that the case represented a victory for the disabled nationwide).

${ }^{251}$ See Daniel Lauber, Group Think: A Recent Supreme Court Ruling Should Make 
The lawsuit was based on a claim of failure to provide reasonable accommodations, but the case failed to illuminate the scope and meaning of the FHAA's "reasonable accommodations" provision. Indeed, Justice Ginsburg, writing for the Court, emphasized that "[t]he sole question before the Court is whether Edmonds's family composition rule qualifies as a 'restrictio[n] regarding the maximum number of occupants permitted to occupy a dwelling' within the meaning of the FHA's absolute exemption. ${ }^{252}$ She dismissed municipal concerns that the decision "will overturn Euclidean zoning" and "destroy the effectiveness and purpose of single-family zoning" ${ }^{253}$ by assuring the city that the issue presented was merely a "threshold question" of "limited scope." ${ }^{254}$ All questions about the meaning of the "reasonable accommodations" clause went unanswered. Although the Court had the opportunity clearly to delineate the provision's parameters, questions regarding the "reasonable accommodations" provision will continue to be answered by lower courts and local governments. ${ }^{255}$

The Edmonds decision is in fact so narrow that it is unlikely to have much impact on anything but municipal reliance on the maximum-occupancy limit exemption. It does absolutely nothing to curtail other local initiatives that use single-family zoning rules to restrict the entry of group homes. Given the limited scope of Edmonds, it is likely that cities and towns will seek to devise comparable alternatives. Indeed, it is also likely that the courts will uphold such practices, provided that they are facially neutral.

One example of such a local initiative is found in the case of Smith $\mathcal{E}$ Lee Associates v. City of Taylor, ${ }^{256}$ a case that did not involve recovering substance abusers but did involve a single-family residential zoning restriction. Like the Seventh Circuit in Palatine

Local Governments Reconsider Their Community Residence Regulations, PlanNING, Oct. 1995, at 11 (inquiring whether the Edmonds decision will cause local and state governments to adjust their zoning regulations to accommodate group homes or merely to rely on alternate methods of excluding such programs), available in LEXIS, News Library, Curnws File.

${ }^{252}$ Edmonds, 115 S. Ct. at 1780 (quoting 42 U.S.C. $\$ 3607$ (b)(1)) (second alteration in original).

${ }^{253} I d$. at 1783 .

${ }^{254} I d$.

${ }^{255}$ This is in direct contrast to the lower court's decision that discusses, in dicta, the meaning of the FHAA's "reasonable accommodations" clause at great length. See City of Edmonds v. Washington State Bldg. Code Council, 18 F.3d 802, 806 (9th Cir. 1994).

${ }^{256} 13$ F.3d 920 (6th Cir. 1993): 
and the Eastern District of Virginia in Virginia Beach, the Sixth Circuit employed a balancing test to assess the meaning of the FHAA's "reasonable accommodations" clause-it weighed local zoning interests against the housing needs of a statutorily protected group of disabled persons. ${ }^{257}$ Like Edmonds, the city of Taylor used a facially neutral definition of family to exclude group homes from a single-family residential neighborhood. Unlike Edmonds, however, Taylor used a different method of excluding the group home ${ }^{258}$-it permitted only nonprofit, rather than for-profit, group homes in single-family residential neighborhoods. With this restriction, it excluded a group of people who were disabled, elderly, and protected under the FHAA from the community. ${ }^{259}$

Smith \& Lee Associates operated a residential program for disabled, elderly individuals. In 1989, when the home was originally established, the company had wanted to house twelve members but was informed that Taylor would not allow it. Because the program required a state license in order to operate, municipal approval was necessary before they could open, regardless of the number of residents they housed. ${ }^{260}$ By state law, however, the municipality was required to permit the inclusion of a residential home for at least six residents. Although the state would certainly allow for more, anything in excess of this six-person minimum obligation was considered to be an issue of local zoning concern. ${ }^{261}$

Lacking any alternative, the program opened with the maximum six-person allotment but quickly found this situation financially infeasible. ${ }^{262}$ In early 1990, Smith \& Lee Associates petitioned

${ }^{257}$ See id. at 931.

${ }^{258}$ Smith $\mathcal{E}^{2}$ Lee Associates $v$. City of Taylor is not a case involving an Oxford House or recovering substance abusers. The practices of Taylor and the legal analysis of the Sixth Circuit are nonetheless relevant as an illustration of the vehicles municipalities use to exclude all group homes and as an example of a court's misinterpretation of the "reasonable accommodations" clause.

${ }^{259}$ See Smith $\mathcal{E}$ Lee Assocs., 13 F.3d at 925.

${ }^{260}$ Given the state licensure requirements for all Adult Foster Care Facilities, Smith \& Lee could not use Oxford House's method of moving in before obtaining municipal permission.

${ }^{261}$ See Smith $\mathcal{E}$ Lee Assocs., 13 F.3d at 923 (citing Mich. CoMP. LAws $\S \S 125.583 \mathrm{~b}(2), 400.716(2)(1993))$.

${ }^{262}$ See United States v. City of Taylor, 798 F. Supp. 442, 444 (E.D. Mich. 1992) (noting that municipal officials refused to issue a building permit until after they were convinced by a state licensing consultant that such a denial would violate both the FHAA and state law), rev'd sub nom. Smith $\mathcal{E}$ Lee Assocs., 13 F.3d 920 . When the permit was eventually issued, it contained the express limitation, "SINGLE FAMILY RESIDENTIAL USE ONLY." See $i d$. 
Taylor to rezone the site. Although none of the neighbors objected at the hearings, although the house was found to be clean and well maintained, ${ }^{263}$ and although there was, at this point, no claim that such rezoning would overburden public facilities or raise problems for traffic, public safety, and similar difficulties, the City Council denied the zoning ordinance. The Council claimed that it was concerned about spot zoning and inconsistencies with the city's master plan. ${ }^{264}$

Smith \& Lee Associates responded with an alternative proposal. Rather than rezone the area, the city could provide a "letter of noopposition" to the Department of Social Services, the state licensing agency, with authority to grant an exception to the single-family area's zoning rule. ${ }^{265}$ It appeared that this exception would be an acceptable alternative given the broad scope of the Taylor's definition of "family," which did not limit the number of unrelated individuals that could reside together. Indeed, the definition was quite broad, providing that even "[a] collective member [sic] of individuals domiciled together in one (1) dwelling unit whose relationship is of a continuing nontransient domestic character and who are cooking and living as a single nonprofit housekeeping unit" could be considered to be a family. ${ }^{266}$ In spite of this liberal language, however, the Council Chairman never even put this proposal to a vote. ${ }^{267}$

The district court that originally heard the case found that Taylor failed to reasonably accommodate Smith \& Lee Associates under the parameters of the FHAA. ${ }^{268}$ The court based its finding partially on the fact that all members of the Taylor City Council testified identically that they were concerned about parking, police, and fire, and that they were concerned about spot zoning. ${ }^{269}$ Their "constant repetition" of precisely the same concerns, along with the fact that the city failed even to study the impact on parking and traffic or the legitimacy of police and fire department concerns, substantially undermined the Council's credibility. ${ }^{270}$ These factors indicated to the courts that the stated fears accompanying

\footnotetext{
${ }^{263}$ See id. at 445.

${ }^{264}$ See Smith $\mathcal{E}^{2}$ Lee Assocs., 13 F.3d at 923.

265 See City of Taylor, 798 F. Supp. at 445.

${ }^{266}$ Smith $\mathcal{E}$ Lee Assocs., $13 \mathrm{~F} .3 \mathrm{~d}$ at 925 (alteration in original).

267 See id. at $923-24$

${ }^{263}$ See Cily of Taylor, 798 F. Supp. at 448 (citing 42 U.S.C. $\$ 3604(f)(3)(B)$ ).

${ }^{269}$ See id. at 446-47.

${ }^{270}$ See id.
} 
home development were clearly pretextual. Unlawful discrimination was at the heart of the decision. Based on this finding, the district court stated that there was "no question" that Taylor could have reasonably accommodated the facility with ease. ${ }^{271}$

The Sixth Circuit overruled this decision and held that Taylor neither intentionally discriminated nor failed to reasonably accommodate Smith \& Lee Associates. ${ }^{272}$ This decision ignored the clear pretext of the city's actions and failed to find discriminatory intent. It also misconstrued the FHAA's "reasonable accommodations" requirement and improperly balanced the city's interest in single-family residential zones against the housing needs of the disabled.

The Sixth Circuit dispensed with the intentional discrimination claim by holding that although a group of twelve unrelated people could go to a traditional landlord and rent a home in a single-family residential neighborhood, a group of elderly Alzheimer's patients could not make the same request of a for-profit agency. The only distinction between the two groups was the fact that the Alzheimer's patients needed to rent from a for-profit agency in order to live in a residential area. Thus, but for the nonprofit requirement of Taylor's zoning provision, a group of twelve unrelated people could live in the single-family residential neighborhood.

The Sixth Circuit's decision in Smith $\mathcal{E}^{\circ}$ Lee Associates also distorted the FHAA's "reasonable accommodations" standard by balancing the city's right to zone against handicapped people's rights to be free from discrimination. ${ }^{273}$ That the home's structure was inconsistent with Taylor's zoning policies-merely because it was a for-profit entity rather than a nonprofit entity-was sufficient reason to refuse issuing the letter of permission.

By drawing this highly dubious distinction between "for-profit" and "not-for-profit" homes, the Sixth Circuit completely missed the point. The court found that Smith \& Lee Associates had not requested changes in zoning laws to accommodate people with disabilities, but rather had sought to accommodate a for-profit enterprise. By leaving individual rights and the needs of the disabled out of the reasonable accommodations equation, Smith $\mathcal{E}^{\circ}$

271 See id. at 447.

${ }_{272}$ See Smith \& Lee Assocs. v. City of Taylor, 13 F.3d at 920, 926 (6th Cir. 1993).

${ }^{273}$ See 13 F.3d at 931 ("We balance the City's interests against the need for an accommodation in this case."). 
Lee Associates effectively crippled the FHAA's "reasonable accommodations" standard.

Once again, the judiciary avoided the FHAA's mandate to prohibit discrimination against recovering substance abusers by balancing the statutory mandate against a municipality's right to zone. The Court in Smith $\mathcal{E}^{\circ}$ Lee Associates failed, in part, because it did not acknowledge that, were it not for the fact that these people were handicapped, they would have been allowed to live in the single-family residential zone. This is precisely the sort of action the FHAA forbids.

\section{REMOVING COMMUNITY AND JUDICIALLY IMPOSED OBSTACLES TO GROUP HOMES FOR RECOVERING SUBSTANCE ABUSERS}

Group homes for recovering substance abusers work, and Congress agrees that they are necessary. Yet communities labor feverishly to exclude these programs, and courts too frequently let cities and towns get away with such efforts. When the problem is put in simple terms, the solution is obvious-courts must more effectively use the legal tools at their disposal to protect the rights of former drug addicts and alcoholics. A person's disabilities, no matter what they are, should not prevent her from realizing the goal of living in a safe, stable neighborhood.

The municipal capacity to regulate land use, however, significantly complicates this matter. Zoning is a well-established, highly valued component of local decisionmaking. ${ }^{274}$ It is not a power cities and towns will voluntarily relinquish. The likelihood of municipalities doing so diminishes even more when such a surrender will benefit former addicts, and when, from the community's standpoint, it threatens community integrity.

The conflict between the FHAA and municipal zoning power requires a judicial solution; one that addresses only reasonable local concerns and one that recognizes Congress's clear statutory mandate. Thus far, most courts have been unwilling to fully accept this responsibility. The judiciary has not only refused to take the remedial action required under the FHAA, it has ignored the subtle discrimination embodied in exclusionary ordinances.

271 See Village of Euclid v. Ambler Realty Co., 272 U.S. 365, 395 (1926) (holding that local legislatures have broad zoning powers). 


\section{A. "Reasonable Accommodations" Means Affirmative Obligation}

Courts must halt local use of the more subtle and complex methods of discriminating against group homes for recovering substance abusers. They can succeed, however, only if $\S 3604(f)(3)$ of the FHAA, the "reasonable accommodations" clause, is given the broad effect Congress intended. This provision requires cities and towns to "make reasonable accommodations in rules, policies, practices, or services, when such accommodations may be necessary to afford such person equal opportunity to use and enjoy a dwelling. ${ }^{275}$ It emphasizes the affirmative obligation cities and towns have to combat housing discrimination; it does not mandate the balancing of housing rights of disabled persons against community self-interest.

Congress included the "reasonable accommodations" clause in the FHAA because it recognized that something more than "even handed treatment" was necessary to combat effectively the stereotyping and segregation of people with disabilities. By directly establishing this additional technique for proving unlawful bias, Congress chose to extend FHAA protections beyond traditional notions of "equal opportunity." It recognized that positive steps must be taken to meet the housing needs of people with disabilities. ${ }^{276}$

The FHAA does not explicitly define "reasonable accommodations." It is clear, however, that the clause should be interpreted like its predecessor, section 504 of the Rehabilitation Act of 1973. ${ }^{277}$ The House Report accompanying the passage of the FHAA supports this interpretation, as does the preamble to HUD's regulations enforcing the statute's provisions. In the House Report, Congress states that the "reasonable accommodations" standard has "a long history in regulations and case law dealing with discrimination on the basis of handicap." 278 Likewise, the Preamble to HUD's FHAA regulations draws a connection between the meaning of reasonable accommodations under section 504 of the Rehabilitation Act and the FHAA. ${ }^{279}$ Both documents cite Southeasterm

${ }^{275} 42$ U.S.C. $\$ 3604(f)(3)$ (1988).

${ }^{276}$ See Simring, supra note 83 , at 427 (discussing the concept of "reasonable accommodations" and the need for individualization).

277 Pub. L. No. 94-112, § 504, 87 Stat. 355, 395 (codified as amended at 29 U.S.C. $\S 794$ (1988 \& Supp. V 1993)).

${ }^{278}$ H.R. REP. NO. 711, supra note 83, at 25, reprinted in 1988 U.S.C.C.A.N. at 2186.

${ }^{279}$ See 54 Fed. Reg. 3232, 3249 (1989) (stating that the "concept of 'reasonable 
Community College v. Davis, the leading case interpreting section 504.280

Section 504 of the Rehabilitation Act clearly contemplates that the needs of people with disabilities be accommodated. This obligation can only be limited if doing so imposes undue financial or administrative burdens upon the party to whom the request is made. Although "fundamental" and "substantial" changes are not required under this standard, many modifications are.$^{281}$ When this requirement is applied to the FHAA, it clearly means that local zoning boards must sometimes overlook limitations on the maximum number of unrelated persons who may reside together and bypass special permitting requirements. Communities have a clear duty to eliminate zoning restrictions that exclude otherwise acceptable group homes from single-family residential neighborhoods. ${ }^{282}$ "[S]trict adherence to a rule which has the effect of precluding handicapped individuals from residing in the residence was precisely the type of conduct which the Fair Housing Amendments Act sought to overcome with the enactment of $\S 3604(f)(3)(B) . "{ }^{283}$

Canons of statutory construction and notions of public policy bolster the argument for an affirmative obligation. As a remedial statute, the FHAA must be interpreted generously and exemptions to it read narrowly. ${ }^{284}$ This canon was particularly significant in

accommodation' is ... . used in regulations and case law interpreting section 504 of the Rehabilitation Act").

${ }^{280} 442$ U.S. 397 (1979) (involving a hearing-impaired woman who was denied admission to a nursing degree program because she could not understand speech without lipreading).

${ }^{281}$ See Simring, supra note 83, at $431 \mathrm{n} .102$ (describing the distinctions among affirmative action, "evenhandedness," and "reasonable accommodations" and explaining reasonable accommodations as "an equal opportunity plus a little something more ${ }^{n}$ ).

${ }^{282}$ See, e.g., Oxford House v. Town of Babylon, 819 F. Supp. 1179, 1186 (E.D.N.Y. 1993).

Because one of the purposes of the reasonable accommodations provision is to address individual needs and respond to individual circumstances, courts have held that municipalities must change, waive, or make exceptions in their zoning rules to afford people with disabilities the same access to housing as those who are without disabilities. Id.

${ }^{283}$ United States v. Village of Marshall, 787 F. Supp. 872, 879 (W.D. Wis. 1991); see also United States v. California Mobile Home Park Mgmt. Co., 29 F.3d 1413, 1416 (9th Cir. 1994) (holding that the "reasonable accommodations" provision "imposes an affirmative duty upon landlords reasonably to accommodate the needs of handicapped persons").

${ }_{284}$ See Trafficante v. Metropolitan Life Ins. Co., 409 U.S. 205, 212 (1972) 
the recent decision, City of Edmonds $v$. Oxford House, Inc. ${ }^{285}$ in which the Supreme Court held that municipalities are not exempt from FHAA coverage when they employ zoning ordinances that limit the number of unrelated persons who may live together in single-family residential neighborhoods. ${ }^{286}$ The Court recognized the FHAA's "broad and inclusive" compass and stated that "generous construction" must guide judicial analysis of the FHAA. ${ }^{287}$ It also noted that the maximum-occupancy limitation is "an exception to 'a general statement of policy' [that must be] sensibly read 'narrowly in order to preserve the primary operation of the [policy]." 288

Furthermore, it is not inappropriate for public interest to influence judicial decisionmaking. Congress has considered the Fair Housing Act to be a policy "of the highest priority." 289 Congress also has "directly endorsed Oxford House ... as an organization worthy of public support because of its role in helping to stem the national epidemic of alcohol and drug abuse. ${ }^{290}$ Just as exemptions to the FHAA must be interpreted narrowly, its remedial provisions must be applied broadly.

Many courts continue to misunderstand this clear legislative directive. Instead of construing the FHAA's "reasonable accommodations" provision requirement, they interpret it as a reasonableness standard. This is a distortion of the statute's plain meaning. "A refusal to make . . accommodations ${ }^{\prime 291}$ is the language of actionit is not the language of degree.

(requiring a generous construction of the Fair Housing Act to achieve its purpose), cited in Califormia Mobile Home Park Mgmt. Co., 29 F.3d. at 1415 (holding that "the FHAA imposes an affirmative duty ... to reasonably accommodate the needs of handicapped persons"); Elliott v. City of Athens, 960 F.2d. 975, 978-79 (11th Cir.) (noting that exemptions to a broad remedial statute must be read narrowly), cert. denied, 113 S. Ct. 376 (1992), cited in City of Edmonds v. Washington State Bldg. Code Council, 18 F.3d 802, 804 (9th Cir. 1994), affd sub nom. City of Edmonds v. Oxford House, Inc., 115 S. Ct. 1776 (1995); Oxford House, Inc. v. City of Va. Beach, 825 F. Supp. 1251, 1258 (E.D. Va. 1993) (noting that exemptions from the FHAA must be "construed narrowly" (citing United States v. Columbus Country Club, 915 F.2d. 887, 883 (3d Cir. 1990), cert. denied, 501 U.S. 205 (1991))).

285115 S. Ct. 1776 (1995).

${ }^{286}$ See id. at $1782-83$.

${ }^{287}$ See id.

${ }^{288}$ Id. (quoting Commissioner v. Clark, 489 U.S. 726, 739 (1989)).

${ }^{289}$ Trafficante v. Metropolitan Life Ins. Co., 409 U.S. 205, 211 (1972).

${ }^{290}$ Oxford House, Inc. v. Township of Cherry Hill, 799 F. Supp. 450, 465 (D.N.J. 1992).

${ }^{291} 42$ U.S.C. $\S 3604(f)(3)(B)$. 
This decided error in interpretation has colored numerous cases involving group homes for recovering substance abusers, particularly United States $v$. Village of Palatine ${ }^{292}$ and Smith $\mathcal{E}^{\circ}$ Lee Associates v. City of Taylor. ${ }^{293}$ Rather than affording group homes the additional protection provided under $\$ 3604(f)(3)(B)$, the courts have employed balancing tests that equated the interests of disabled people with those of the community as a whole. In Palatine, the result was to require Oxford House to submit to a process that was, even in the court's eyes, probably discriminatory. ${ }^{294}$ In Smith $\mathcal{E}^{\circ}$ Lee Associates, it meant that even though "the handicapped may have little choice but to live in a commercial home if they desire to live in a residential neighborhood," the town was legally able to completely exclude them. ${ }^{295}$

Despite the judicial tendency to misconstrue the meaning of the FHAA's "reasonable accommodations" clause, a few decisions have favored the better approach. The most notable and accurate interpretation of this provision can be found in the Ninth Circuit's decision in City of Edmonds $v$. Washington State Building Code Council. ${ }^{296}$ Reasonable accommodations, the court contemplated, means more than a mere balancing of a municipality's right to zone against the needs of people with disabilities. Instead, it "imposes an affirmative duty" on towns and cities to facilitate the housing of handicapped people in the community of their choice. ${ }^{297}$ This interpretation, the court noted, was especially appropriate in view of congressional intent. "Courts must ask whether . . . a city has to alter neutral zoning policies to reasonably accommodate and integrate handicapped persons." 298 If the answer is "yes," something more than facial neutrality may indeed be necessary. ${ }^{299}$

\footnotetext{
29237 F.3d 1230 (7th Cir. 1994).

29313 F.3d 920 (6th Cir. 1993).

${ }^{294}$ See supra notes $230-40$ and accompanying text.

$29513 \mathrm{~F} .3 \mathrm{~d}$ at 931.

296 18 F.3d 802 (9th Cir. 1994), affd sub nom. City of Edmonds v. Oxford House, Inc., $115 \mathrm{~S}$. Ct. 1776 (1995).

${ }^{297}$ See id. at 805.

298 Id. at 806.

${ }^{299}$ See id.
} 


\section{B. Rethinking Definitions That Limit Access to Group Homes}

If they are to protect effectively the housing rights of recovering substance abusers, courts must also give closer scrutiny to facially neutral zoning ordinances that limit access to group homes. Local limitations on the definition of single-family residential zones must be more liberally construed. This obligation is not only consistent with Congress's intent, but it is a component of the FHAA's "reasonable accommodations" standard.

To achieve the goals of the FHAA and to protect recovering substance abusers from discrimination, definitions of the "family" should also be interpreted broadly. Frequently, local definitions of single-family residential zones pose more stringent requirements on groups of unrelated individuals than on those related by blood or marriage. ${ }^{300}$ These definitions operate to the clear disadvantage of disabled people who seek to live in group homes. For many disabled people, it is often not possible, because of their physical impairments or emotional difficulties, to live with relatives. ${ }^{301}$ This circumstance is particularly true for many recovering alcoholics or drug addicts, who are highly susceptible to relapse if they do not live in a supportive, safe environment. ${ }^{302}$ Seeking such a place, Oxford House has modeled itself around the concept of "family." Each house is self-sufficient and self-run. Residents share responsibilities, focus on tolerance and respect, and live together in a communal environment. ${ }^{303}$ Indeed, Oxford Houses and other group homes that operate as functional families may be considered families by operation of law in at least one state. ${ }^{304}$

${ }^{300}$ See, e.g., Oxford House, Inc. v. Township of Cherry Hill, 799 F. Supp. 450, 455 (D.N.J. 1992) (describing a local ordinance in which a group of unrelated individuals were presumed not to constitute a family until they met a "permanency and stability" standard, whereas related individuals were automatically granted family status); see also Smith \& Lee Assocs. v. City of Taylor, 13 F.3d 920, 926 (6th Cir. 1993) (imposing a distinction between commercial and nonprofit group homes).

${ }^{301}$ See, e.g., Smith $\mathcal{E}$ Lee Assocs., 13 F.3d. at 920-22 (describing the program's residents as elderly and disabled, often suffering from Alzheimer's disease and related ailments).

${ }^{302}$ See, e.g., Township of Cherry Hill, 799 F. Supp. at 457 n.13 (describing what would happen if Oxford House were to close).

${ }^{303}$ See MOLLOY, supra note 4 , app. B.

${ }^{304}$ See Baer v. Town of Brookhaven, 537 N.E.2d 619, 619 (N.Y. 1989) (holding that the definition of the term "family" contained in the zoning ordinance of the Town of Brookhaven violated the due process clause of the New York Constitution because the definition excluded from its scope the type of "surrogate" families that reside in 
To facilitate the recovery of substance abusers, an inclusive definition of "family" is necessary. A definition that includes selfsupported, democratically operated group homes is not nearly as radical as it initially appears. Group homes for recovering substance abusers are not merely rooming houses. Residents of Oxford Houses "share more than 'household responsibilities[,]' ... [they] make all house decisions in a democratic fashion ... [and] the support they lend each other is therapeutic ...."305 They behave like many families do, but lack the formality of filial allegiance. Indeed, mental heath experts agree that it is appropriate to characterize group homes as functional families. ${ }^{306}$ Like families, members of group homes create "myths" based on group experiences that represent a sense of shared history, they develop specific expectations of their community members, they form networks of in-law type relationships, and they feel abandoned and disappointed when a member fails or leaves. ${ }^{307}$

The functional family, consisting of single parents, stepparents, roommate situations, and homosexual and heterosexual cohabitation is sharply on the rise, while the traditional family is rapidly becoming outdated. ${ }^{308}$ Furthermore, the need to end discrimination has never been more apparent. Two states have recognized this. The highest courts of New York and New Jersey have ruled that municipalities may address only certain characteristics of the traditional family in delineating acceptable single-family home membership. ${ }^{309}$ New Jersey courts, for example, use a "single

group homes).

${ }^{305}$ Oxford House-Evergreen v. City of Plainfield, 769 F. Supp. 1329, 1335 (D.N.J. 1991).

${ }^{306}$ See Barbara L. Fenby, The Community Residence As a Family: In the Name of the Father, 5 J. INDEPENDENT SOC. WORK 121, 123-24 (1991) (describing the family as the pattern for community residences).

${ }^{307}$ See id. at 124-28.

${ }^{203}$ See Note, Looking for a Family Resemblance: The Limits of the Functional Approach to the Legal Definition of Family, 104 HARV. L. REv. 1640, 1640 (1991) (arguing that the "traditional nuclear family is rapidly becoming an American anachronism"); see also Gerald Korngold, Single Family Use Covenants: For Achieving a Balance Between Traditional Family Life and Individual Autonomy, 22 U.C. DAvIS L. REv. 951, 952-53 (1989) (noting the increase in nontraditional family structures).

${ }^{309}$ See State v. Baker, 405 A.2d 368, 375 \& n.10 (N.J. 1979) (holding that an ordinance that prohibited more than four unrelated persons from sharing a single housing unit in the case of two nuclear families seeking to reside together partly for religious reasons violates rights of privacy inherent in the due process clause of the New Jersey Constitution); McMinn v. Town of Oyster Bay, 488 N.E.2d 1240, 1244 (N.Y.1985) (invalidating a zoning rule that limited occupancy of single-family homes to persons related by blood, marriage, or adoption or to two unrelated persons 
housekeeping unit" standard, rather than biological or legal relationships, to define a family. ${ }^{310}$

Except for two distinctions-that residents are not related to each other and that they have acknowledged and are attempting to overcome their addiction-how are Oxford House residents any different than many families? To be certain, there are many substance abusers who have yet to seek treatment and live in all sorts of homes in all sorts of cities. Should not some accommodation be granted to those who have the courage to step forward and attempt to heal themselves? In light of the FHAA's "reasonable accommodations" provision, and in conjunction with Congress's dual intentions of ending discrimination against people with disabilities $^{311}$ and promoting drug and alcohol rehabilitation through community integration, ${ }^{312}$ it is clear that members of a group home for recovering substance abusers should be permitted to label themselves as a family.

\section{Recognizing and Removing Subtle Barriers to Group Homes for Recovering Substance Abusers}

The FHAA certainly has its deficiencies, but it nevertheless has had a substantial impact upon the way municipalities can keep unwanted populations out of their neighborhoods. Judicial enforcement of the Act's provisions, although inadequate, now keeps many cities and towns from enacting local ordinances that directly exclude or have the effect of excluding group homes for recovering substance abusers from single-family residential neighborhoods. Yet, despite these strides, communities have proven to be extraordinarily adaptable. As quickly as courts invalidate one exclusionary zoning tactic, communities devise another, more insidious successor.

sixty-two years of age or older on the basis that the rule violates the due process clause of the New York Constitution).

${ }^{310}$ See Baker, 405 A.2d at 372; see also Richards, supra note 192, at 790-91 (noting that "[s]ome state courts ... in addition to striking down traditional-family ordinances, have ruled that a local governing body may deal only with certain characteristics of the traditional family in regulating the membership of household units"); cf. Martha Minow, The Free Exercise of Families, 1991 U. ILL. L. REv. 925, 92527 (employing a constitutional analysis of the changing nature of families in a time of increasing challenges to civil liberties).

311 See supra notes 88-94 (discussing the purposes of the FHAA).

312 See supra notes 70-81 and accompanying text (discussing the Anti-Drug Abuse Act of 1988). 
The Supreme Court's decision in City of Edmonds v. Oxford House, Inc. and its respective fallout provides a fitting example of this phenomenon. Before this case, maximum-occupancy limitations in single-family residential neighborhoods had been a favored tool of communities opposed to group homes. ${ }^{313}$ Indeed, a substantial part of their allure was that they did not appear as harsh as many other discriminatory measures. Then, the Court held that this tactic may violate the FHAA. ${ }^{314}$ Although it is too early to draw certain conclusions, it is not unlikely that the Edmonds decision will prompt communities to develop newer, more sophisticated, less recognizable modes of discrimination. Such development has, in fact, already begun.

In the Pittsburgh area, for example, local leaders could not return to the drawing board fast enough. One suburban town official who was in the midst of a zoning battle involving a group home when the Supreme Court handed down the Edmonds decision immediately recognized that he would have to change tactics. Because numerical limitations could no longer permissibly bar people with disabilities, he responded by planning to use space requirements to limit group homes. ${ }^{315}$ In Pittsburgh proper, it took the city council president and multiple neighborhood groups less than a month to hold hearings and make new proposals capable of skirting the FHAA and the Supreme Court's decision. ${ }^{316}$ A key component of many of these provisions is a spacing requirement. For instance, the Pittsburgh proposal includes one that restricts any new facility from opening within 500 feet of another. ${ }^{317}$ New Jersey's Municipal Land Use Law suggests, among other things, that no community residence be located within 1500 feet of another. ${ }^{318}$

${ }^{313}$ See J. Kenneth Evans, Ruling Puts Group Home Laws in Question, PITTSBURGH POST-GAzETTE, May 31, 1995, at N1 (stating that the Supreme Court's decision in $E d m o n d s$ had sent "municipalities across the country scurrying to rewrite zoning ordinances"). For instance, in Allegheny County, Pennsylvania, a local official estimated that more than half of the region's communities employed these types of ordinances. See id.

${ }^{314}$ See City of Edmonds v. Oxford House, Inc., 115 S. Ct. 1776, 1783 (1995).

315 See Evans, supra note 313, at N1 (describing how the City Solicitor may employ tactics that avoid altogether the maximum-occupancy limit standard).

${ }^{316}$ See Gary Rotstein, City Airs Plans for New Rules on Group Homes, PITTSBURGH Post-GazeTTE, June 14, 1995, at B5 (describing how neighborhood groups are looking forward to this process to strengthen, rather than to liberalize, restrictions against group homes).

${ }^{317}$ See id.

${ }^{318}$ See N.J. STAT. ANN. § 40:55D-66.1 (West 1991); see also David P. Lazarus \& Susan DiMaria, Housing Discrimination and the Disabled, 170 N.J. LAw. 20, 23 (1995) 
Another popular technique to block group homes is the use of variance hearings and extensive conditional-use permitting processes. $^{319}$ Like maximum-occupancy limits on the number of unrelated persons who may live in single-family residential neighborhoods, such requirements for public notice and comment too frequently disguise discrimination against recovering substance abusers under facially neutral rules. Unlike maximum-occupancy limits, courts do not uniformly find them to be illegal. Thus, while group homes may have won one battle, they still run the risk of losing the war.

Gities and towns are likely step up their efforts to employ hearing and notice requirements in situations involving group homes for recovering substance abusers. They may do so to substitute for the loss of their other favorite technique-the maximum-occupancy limit. They may be further encouraged as people living in residential communities demand increasing amounts of information about who their neighbors are. ${ }^{320}$

Neighborhoods also may step up their protests against group homes by asserting their rights to free speech. ${ }^{321}$ Indeed, four Senators recently introduced the Fair Housing Reform and Freedom of Speech Act of 1995. ${ }^{322}$ This proposal, in part, seeks to tie the hands of HUD officials who are trying to protect the housing rights of disabled persons and keep residents from intimidating prospective group home occupants. ${ }^{323}$ Not surprisingly, the other component of the bill seeks to overturn Edmonds and reestablish a municipality's right to employ maximum-occupancy limitations free

(surveying the systematic and pervasive legal barriers disguised as neutral zoning ordinances that exclude community residences).

${ }^{319}$ See supra part III.B.2.

${ }^{320}$ See Tracy L. Silva, Comment, Dial "1-900-Pervert" and Other Statutory Measures That Provide Public Notification of Sex Offenders, 48 SMU L. Rev. 1961, 1968-79 (1995) (surveying federal and state statutes and initiatives, as well as relevant court decisions); see also supra note 190 and accompanying text (discussing the rise of neighbor notification statutes).

${ }^{321}$ See James H. Andrews, U.S. Housing Agency to Issue Guidelines Protecting Free Speech in Bias Problems, Christian SCI. MONITOR, Sept. 1, 1994, at 3 (discussing changing HUD policy regarding the free speech rights of community members who protest against plans to place group homes in their neighborhoods and describing recent controversies regarding the First Amendment and the FHAA in Berkeley, California and New York City).

${ }^{322}$ See S. 1132, 104th Cong., 1st Sess. (1995); 141 CoNG. REC. S12,079 (daily ed. Aug. 9, 1995).

${ }^{323}$ See S. 1132, supra note $322, \S 2(\mathrm{~b})$. 
from FHAA obligations and to protect them as a way to keep group homes out of single-family neighborhoods. ${ }^{324}$

\section{CONCLUSION}

When communities oppose group homes for recovering substance abusers, and when the judiciary allows this to happen, the consequences are severe and unfortunate. Not only does such resistance perpetuate unfounded and unacceptable biases, but it hinders recovery from drug and alcohol addiction. Single-family zoning ordinances that exclude recovery houses are detrimental both to people who have such disabilities and to the general welfare.

Group homes serving former drug addicts and alcoholics function best when they are located in safe, stable, residential neighborhoods. Yet, these communities are the ones that mount the most pervasive and, indeed, most effective opposition to such programs. When local resistance successfully prevents recovery houses from being established, people are kept from participating in one of the most effective, least expensive methods of drug rehabilitation. Furthermore, when single-family zoning laws exclude group homes, these programs are forced to locate in neighborhoods that are far less appropriate.

The "not in my backyard" attitude harms not only people with disabilities, but places additional burdens on those communities that are not capable of mounting opposition. ${ }^{325}$ Most frequently, these are poor communities that are already saturated with similar programs and are least able to provide the kind of environment recovering substance abusers require. ${ }^{326}$ The upshot is an increas-

${ }^{324}$ See id. § 2(a).

My bill would clarify that localities can continue to zone certain areas as single family neighborhoods, by limiting the number of unrelated occupants living together. In my opinion, I think families should be able to live in neighborhoods without the threat that groups homes-unsuitable for single family neighborhoods-can move in next door and receive the protection of the Fair Housing Act.

141 CoNG. REC., supra note 322, at S12,079 (statement of Sen. Faircloth).

${ }^{325} \mathrm{Cf}$. Michael B. Gerrard, The Victims of NIMBY, 21 FordHAM URB. L.J. 495, 520 (1994) ("If . . . minority groups are unable to find housing in more affluent neighborhoods in the city or in the suburbs, they may be more likely to remain in urban ghettos, where drug addiction, violence, and other social ... ills are heavily concentrated.").

${ }^{326}$ See Margulies, supra note 186 , at $962-63$.

Poor communities' lack of access to this repertoire of resistance reinforces market tendencies to concentrate human service facilities in low-income 
ing spiral of addiction and crime. The communities used as dumping grounds are spread even thinner, and the people are forced into neighborhoods where there is a far greater likelihood of relapse.

The conflict between municipal zoning codes and group homes for former substance abusers raises not only issues of individual rights and local power, but it also challenges the national commitment to drug and alcohol rehabilitation. Americans say they want to win the War on Drugs. But unless addicts are given the chance to recover, there is little doubt that they will end up back on the streets, committing crimes, remaining outside productive society, and buying drugs.

neighborhoods. It is cheaper to locate human services in neighborhoods where real estate is less valuable, rather than using "prime" land crying out for luxury condominiums. Ironically, communities used as "dumping grounds" tend to have fragile support systems which are least able to meet the needs of citizens receiving services.

Id. Indeed, concerns regarding community saturation by group homes are raised with increasing frequency. See, e.g., Ruben Castaneda, Drug Program, Zoning Rules Collide: D.C. Decision Threatens Group Homes for Recovering Addicts, WASH. POST, May 4, 1993, at B1 (discussing complaints in one Washington, D.C. neighborhood of being "overburdened with shelters for the homeless, group homes for juvenile delinquents and unwed mothers, and similar facilities"). 